San Jose State University

SJSU ScholarWorks

Master's Projects

Master's Theses and Graduate Research

Spring 2018

\title{
Leveraging the Workforce Innovation \& Opportunity Act (WIOA) to Help Finance College \& University Career Centers
}

Daniel Newell

San Jose State University

Follow this and additional works at: https://scholarworks.sjsu.edu/etd_projects

Part of the Other Public Affairs, Public Policy and Public Administration Commons, Policy Design, Analysis, and Evaluation Commons, Public Administration Commons, and the Student Counseling and Personnel Services Commons

\section{Recommended Citation}

Newell, Daniel, "Leveraging the Workforce Innovation \& Opportunity Act (WIOA) to Help Finance College \& University Career Centers" (2018). Master's Projects. 584.

DOI: https://doi.org/10.31979/etd.cnre-6mxb

https://scholarworks.sjsu.edu/etd_projects/584

This Master's Project is brought to you for free and open access by the Master's Theses and Graduate Research at SJSU ScholarWorks. It has been accepted for inclusion in Master's Projects by an authorized administrator of SJSU ScholarWorks. For more information, please contact scholarworks@sjsu.edu. 
LEVERAGING THE WORKFORCE INNOVATION \& OPPORTUNITY ACT (WIOA) TO HELP FINANCE COLLEGE \& UNIVERSITY CAREER CENTERS

\author{
by \\ Daniel Newell
}

A Thesis Quality Research Project Submitted in Partial Fulfillment of the

Requirements for the

Master's Degree

in

PUBLIC ADMINISTRATION

Prof. Frances L. Edwards, Ph.D.

The Graduate School

San Jose State University

May 2018 
2) P a g e 


\section{BACKGROUND}

Can funding and career services for the adult and dislocated worker population of the Workforce Innovation and Opportunity Act (WIOA) be leveraged to serve a college student population while meeting WIOA's enrollment goals? This research looks at leveraging WIOA financial resources to serve the public as well as a college student population while meeting WIOA mandates.

WIOA funded career centers are known as American Job Centers (AJCs). In California, they are referred to as America's Job Centers of California (AJCCs). AJCs are career centers that help job seekers explore careers, train for the workforce, and find employment (Ross \& Holmes, 2017). AJCs are located in each state and throughout every region of the country (United States Department of Labor [DOL], 2013). This research explores whether WIOA funding can be leveraged to provide career services in a college or university setting to serve students and the public. For colleges and universities without career centers, leveraging WIOA funding may be a solution to increasing career center resources and expanding existing career services, while augmenting program support through federal funding.

On July 22, 2014, President Barack Obama signed the Workforce Innovation and Opportunity Act (WIOA), a landmark piece of bipartisan legislation that reformed the public workforce system after 15 years of operating under the Workforce Investment Act (WIA) (United States Department of Labor [DOL], nd). WIOA has been described as the "primary architect" for America's national workforce development system (Ross \& Holmes, 2017). WIOA authorizes funding to support approximately 2,500 AJCs to help job seekers access employment, education, and training services and resources (Ross \& Holmes, 2017). 
AJCs are open to the public and located in communities in every state across America (Department of Labor, 2013). AJCC success is measured in part by a series of outcomes that include job seeker enrollment, training, and employment (DOL, nd).This research explores whether career services for the adult and dislocated worker populations of the WIOA can be leveraged to serve a college student population while meeting WIOA's enrollment goals.

\section{Evolution of the Federal Workforce Development System}

The federal workforce development system has evolved over the $20^{\text {th }}$ century, and during that time many pieces of federal legislation were introduced and reformed. Commonalities between the legislation are focused on training/education and employment. It was not until the Manpower Development and Training Act of 1962 under the Kennedy Administration that the federal employment service and vocational education system were brought together to begin to establish a federal workforce development network or system (Guttman, 1983). The integration of the two systems has been described as a "treaty" (Guttman, 1983). The Manpower Development and Training Act then evolved into the Comprehensive Employment and Training Act of 1973 under the Nixon Administration (Bassi, 1983). The Comprehensive Employment and Training Act originally focused on training job seekers, then, between 1974-1975 during a national recession, it shifted gears to focus on employment, then eventually it shifted back to focus on training (Bassi, 1983). The Comprehensive Employment and Training Act was reformed and became the Job Training Partnership Act of 1983 under the Reagan Administration, and focused on helping economically disadvantaged populations find employment or "better" jobs (Anderson \& Burkhauser, 1991). Then in 1998, the Job Training Partnership Act evolved again to become the Workforce Investment Act (WIA) under the Clinton Administration (Decker, 2011). WIA 
focused on streamlining services, empowering individuals, providing universal access to services, increasing accountability, engaging the private sector, ensuring state and local flexibility, and fundamentally changing the services provided to youth (Decker, 2011). Then, in 2014, the Obama Administration replaced WIA with America's current workforce development system called the Workforce Innovation and Opportunity Act (WIOA) (Guttman, 1983).

Figure 1: Evolution of the Federal Workforce Development System

\section{Evolution of the Federal Workforce Development System}

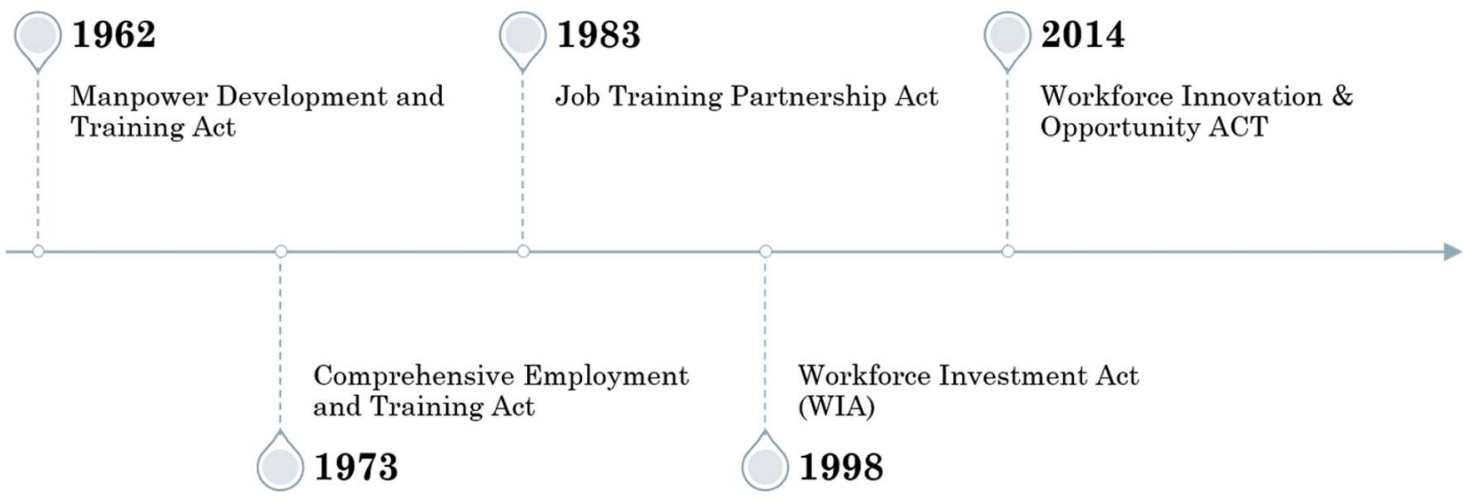

\section{College/University Career Centers}

According to Career Counselor and Program Lead for the Career Center at San Jose State University, Nellie Rochon-Ellis, who has over 10 years' experience in career services, and has worked for both WIA and university career services, career centers, also referred to as "career services" in institutions of higher education, are common at colleges and universities and are 
frequently housed in departments under Student Affairs or Student Services (N. Rochon-Ellis, personal communication, Mar 27, 2018). According to the Senior Employer Relations and Workforce Analyst at the Career Center for Sacramento State University, Mary Kober, who has over 20 years' experience working in both WIA and university career services, college/university career centers offer many of the same services and resources as AJCs, and they sometimes collaborate (M. Kober, personal communication, Apr 6, 2018).

In recent years there has been much debate about the value of a college degree, as showcased in the film Ivory Tower by CNN Films (Rossi, 2014). Students and parents sometimes express concern about whether college and university credential and degree programs lead to strong employment prospects. (N. Rochon-Ellis, personal communication, Mar 27, 2018). According to Interim Director and Counselor at Ohlone College, Nancy Navarro-Leca, who has over seven years' experience working in university and community college counseling, many community colleges focus on preparing students for transfer to university baccalaureate programs (N. Navarro-Leca, personal communication, April 5, 2018), while many university programs focus on developing students for continued education and research, instead of occupational training to enter the workforce (M. Kober, personal communication, Apr 6, 2018 $\&$ N. Rochon-Ellis, personal communication, Mar 27, 2018). Many academic programs make strong attempts to align curriculum and educational tracks to the workforce to prepare students for the world of work (M. Kober \& N. Rochon-Ellis, personal communication, Apr 6, 2018 \& Mar 27, 2018).

Many colleges and universities have career centers or provide career services. In the CSU system, many career centers have a small number of staff and are under-resourced to meet demand Some CSU career centers have been absorbed by academic counseling services and 
departments (N. Rochon-Ellis, personal communication, Mar 27, 2018). From exploring California community college and university websites, results indicate that some colleges and universities do not have career centers. In the California community college system, for example, many colleges do not have formal career centers to support student employment, and instead, career services are provided by counselors who work as part of transfer centers that focus on academic counseling and supporting student transfers to four-year degree programs (N. NavarroLeca, personal communication, Apr 5, 2018).

Although they offer similar services, college/university career centers operate very differently than AJCs and often lack formal oversight and accountability for employment outcomes (M. Kober, personal communication, Apr 6, 2018 \& \& N. Rochon-Ellis, personal communication, Mar 27, 2018). This means that college and university career centers are not required to find anyone a job or internship, and are not contractually accountable for employment outcomes like AJCs. College and university career centers sometimes operate as silos and do not belong to local, state, or national systems like their federal counterparts, the AJCs (M. Kober, \& personal communication, Apr 6, 2018 \& N. Rochon-Ellis, personal communication, Mar 27, 2018).

\section{Ohlone College Tri-Cities Career Center: an American Job Center}

In California, the Alameda County Workforce Development Board (ACWDB) implements the WIOA program for most Alameda County cities and manages a network of WIOA supported career centers or AJCCs (Alameda County Workforce Development Board, nd). One of the ACWDB's AJCC sites is located at Ohlone Community College (CA.GOV, 2013). Ohlone's AJCC, known as the Tri-Cities One-Stop Career Center, is uniquely positioned to answer 
whether career services for the adult and dislocated worker population of the WIOA can be leveraged to serve a college student population while meeting WIOA's enrollment goals. The Tri-Cities One-Stop Career Center is a federally funded career center, part of the AJCC system, and is located on a community college campus (Ohlone, nd). The Tri-Cities One-Stop Career Center operates as an AJCC, not a college career center. However, according to a Career Advisor at Ohlone College's Tri-Cities Career Center, Shirley Calvert, who has over 20 years' experience coordinating WIA and WIOA career services, the career center at Ohlone reports to both the ACWDB and Ohlone administration (S. Calvert, personal communication, Apr 4, 2018), a truly unique opportunity for a hybrid career center, and a perfect organization to test the hypothesis that an AJCC can operate as both an AJC and college career center while meeting WIOA and college administration goals.

If WIOA mandates can be met while serving community members and students, WIOA may be a solution to help support the creation or expansion of career centers in colleges and universities across the country. If WIOA mandates can be met while serving students and the public, colleges and universities without career centers may be able to leverage WIOA funding, enabling them to provide career services to their students and the community, while augmenting revenue through federal dollars.

Calvert states that the ACWDB provides oversight to AJCCs to ensure career center accountability for enrollment, training and employment outcomes for job seekers (S. Calvert, personal communication, Apr 4,2018). This research focuses on enrollment requirements as outlined by Ohlone's workforce program specialist who processes and confirms program participant eligibility requirements. According to a Workforce Program Specialist for Ohlone College's Tri-Cities Career Center, Jesus Jimenez, who has five years' experience in WIA and 
WIOA career services, and who is responsible for processing and verifying program eligibility, enrollment requirements are categorized into two populations: adults and dislocated workers (J. Jimenez, personal communication, April 4, 2018). Adult and dislocated worker classifications share some eligibility criteria.

Shared criteria:

- Job seekers must be residents of Alameda County or must have worked in Alameda County in the past six months; must be eligible and furnish proof to work in the United States; must be registered in Selective Service, if applicable; must be age 18 or over (Ohlone College, 2018).

In addition to adult and dislocated workers having to meet the shared criteria, each population must meet additional criteria.

Adult enrollment parameters:

- A minimum of $51 \%$ of enrolled adults must be part of a "priority population"; priority populations include individuals with disabilities, veterans and/or their eligible spouses, individuals who are low-income, individuals who are basic-skills deficient (under eighth grade reading, writing, and math skills), individuals with a criminal background (reentry), and individuals enrolled in adult education programs (J. Jimenez, personal communication, April 4, 2018).

Dislocated Worker enrollee parameters:

- Laid off from their former employer, or current recipient of unemployment insurance benefits, or received unemployment insurance benefits during sometime in the last five years (J. Jimenez, personal communication, April 4, 2018). 
Ohlone's WIOA contract requirements mandate that 178 job seekers must enroll in the program (Browning \& Cox, 2017). Of these job seeker enrollments, 91 must be recipients of unemployment or laid-off workers (i.e., dislocated workers (DW)), 81 must be non-laid off workers and $51 \%$ of those, or 41 , must fall into a priority population (Browning \& Cox, 2017 and J. Jimenez, personal communication, Apr 4, 2018). Ohlone Received approximately $\$ 520,000.000$ for a 12 -month period to meet these WIOA contract requirements (Browning \& Cox, 2017).

This research uses the above criteria to determine whether career services for the adult and dislocated worker populations of the WIOA program can be leveraged to serve a college student population while meeting WIOA's enrollment goals. 


\section{LITERATURE REVIEW}

Research on California community college and university websites shows that some AJCCs are part of California's community college system, however, they act as silos or separate entities of the college and do not focus on students. The intent of this literature review is to explore existing literature and research pertaining to AJCs and college/university career centers to determine the extent to which WIOA has been leveraged to support college career centers.

To understand if an AJC can be used to serve as a unit of the federal workforce development system and a college/university career center, this literature highlights elements of WIOA's background and legislative objectives, developments in the relationship of post-secondary education and employment, and current approaches to college/university career centers.

\section{Workforce Investment Act (WIA) to Workforce Innovation \& Opportunity Act (WIOA)}

The history of WIOA is limited because it is a newly revised rendition of its predecessor, the Workforce Innovation Act (WIA) of 1998, and was signed into law on July 22, 2014 (DOL, nd). According to Ohlone's workforce program specialist, the final WIOA mandates were integrated into the 2017/2018 program year (July 1, 2017 - June 30, 2018) for the ACWDB (J. Jimenez, personal communication, 2018).

WIA was designed to include greater collaboration among workforce organizations like educational institutions, disability services, and other partners (Cohen \& Fesko, 2005). To facilitate collaboration, efforts were made to designate public career centers as "One-Stop" centers (Cohen \& Fesko, 2005). WIA focuses on interagency collaboration to help job seekers

obtain employment (Cohen \& Fesko, 2005). The WIOA program has two key stakeholders: employers and job seekers (Holland, 2016). The term "One-Stop Career Center" was the name for the federal workforce development system's career centers before their recently revised name 11 I P a g e 
to American Job Centers (AJCs) and America's Job Centers of California (AJCCs) (M. Kober, personal communication, Apr 6,2018). Calvert states that an important component of the WIA and the WIOA programs is paid training (S. Calvert, personal communication, April 4, 2018). Paid training is offered to job seekers so they can acquire new skills to meet the industry workforce demands (S. Calvert, personal communication, April 4, 2018); training is industry recognized and considered "market-driven education" (Shaw \& Rab, 2003). Colleges are viewed as links between education and industry, and between K-12 education and 4-year universities (Shaw \& Rab, 2003). These links may make colleges attractive venues to serve job seekers who require further training/education. Although colleges were used to provide industry-recognized training paid by WIA dollars, that appears to be the extent of the relationships between One-stop centers and higher education. One study acknowledges that whether the WIA policies serve the needs of students is still an unanswered question (Shaw \& Rab, 2003).

WIOA serves as a universal access point for job seekers to obtain career development, training, and employment services (M. Kober, personal communication, Apr 6, 2018). WIOA pays for industry-recognized training for job seekers that are frequently offered by educational institutions (Calvert, personal communication, April 4, 2018). Job seekers served by the WIOA program are not classified as students, although WIOA clients receiving training funded by the WIOA program are often students in some capacity, due to them having to enroll into an educational program and institution. Three core classifications of job seekers that WIOA acknowledges include Adults, Dislocated Workers, and Youth (Decker \& Berk, 2011). Although a student job seeker can be part of any of the three classifications, current research does not indicate that AJCCs attempt to prioritize or target job seekers enrolled in college. 
Education and training is a Key Performance Indicator (KPI) of WIOA (J. Jimenez, personal communication, April 4, 2018). WIOA focuses on enrollments, employment outcomes, and median earning (Ginn, 2015). In earlier proposals when transitioning from WIA to WIOA, the three populations of job seekers were to be consolidated into one allotment, however, currently they remain separated as three different populations/allotments (Holland, 2016) reporting a common set of performance indicators (Ginn, 2015).

\section{WIOA Training}

Research shows that jobs are becoming more complex, and high-paying jobs require cognitive and communication skills acquired by post-secondary education (N. Rochon-Ellis, personal communication, Mar 27, 2018). However, those jobs do not necessarily require a bachelor's degree, and can be filled by candidates from a certificate or two-year degree program; these jobs are often filled by a more highly skilled worker (Holzer, 2013). AJCs provide access for job seekers to receive training. Colleges offer many training and educational programs, yet many AJCs are not part of a college system. Student graduates from college certificate and degree programs serve as a natural fit for AJC services. Colleges provide training/education and offer an abundance of other resources for students. The California Bay Area is not the only region to house an AJC at a college. The desire for an AJC to serve students is shared by other educational administrators who believe that a WIOA career center can be used to provide student services (katc.com, 2017).

WIOA program success has been attributed to close relationships between employers, training providers, and staff helping job seekers maneuver through the system (Holzer, 2012). Training providers are educational institutions that offer industry-recognized training programs 
(S. Calvert, personal communication, Apr 4, 2018). Training and workforce needs are often regional, so the workforce development system under WIA proved to be effective in facilitating regional efforts, both intrastate and interstate (Mason, 2008). Collaboration on regional levels between AJCs can be an important tool for deploying a sustainable workforce system that develops human capital to meet the knowledge and expertise required for sectors like science, technology, engineering, and mathematics (STEM) (Kleinbach-Sauter, Ganapathy, \& Fraser, 2015) and other sectors where AJCs and colleges reside. Two-year and 4-year college systems like the California Community College (CCC) and California State University (CSU) systems are established systems equipped to provide continuing training and education, and they serve as recruiting grounds for thousands of employers, yet they remain as virtually untapped conduits for WIOA implementation.

It has been established that AJCs support job seekers by providing employment services and by providing training opportunities. Training opportunities come in the form of post-secondary education, and the opportunities can be offered by colleges and universities. Both community colleges and universities are equipped to provide short-term educational programming. Community colleges and universities offer certificate programs and have wide access to networks of employers. The WIOA program supports opportunities for students to engage in internship programs to help train them in real-world work environments while providing a footin-the-door to employers (Ray-Leonetti, 2017). Internship programs are a great way for an individual to receive current and applicable training. The infrastructure for AJCs to serve college students is already in place; it seems possible for AJCs to expand to serve as both an AJC and a college/university career center. College/university career centers can help align campus goals 
like student achievement by supporting work-based learning opportunities, and by graduating students with industry-recognized credentials (Studley, 2016).

\section{Evolution of Career Centers in Higher Education}

Although colleges and universities offer short-term training and educational programming, there seems to be a disparity between the responsibilities and perceptions of a college/university career center. Although an AJC's approach to career services is based in part on job search, placement assistance, career counseling, skills training and employment outcomes (Marquette, 2016), college/university career center success is less defined and lacks a shared system of local, state, or federal measurements and outcomes (M. Kober, personal communication, Apr 6, 2018 \& N. Rochon-Ellis, personal communication, Mar 27, 2018). Career services in higher education have undergone various renditions over the past 100 years. Like WIOA, which evolved from various training initiatives since the 1960s, career services in higher education has roots from the early 1900s, when it evolved from various approaches that included vocational guidance (1900 1920), teacher guidance (1920 - 1940), job placement (1940-1970), career counseling (1970 1990), professional networking (1990 - 2010), to its current focus on connected communities (2010 - 2030) (Dey \& Cruzvergara, 2015). 


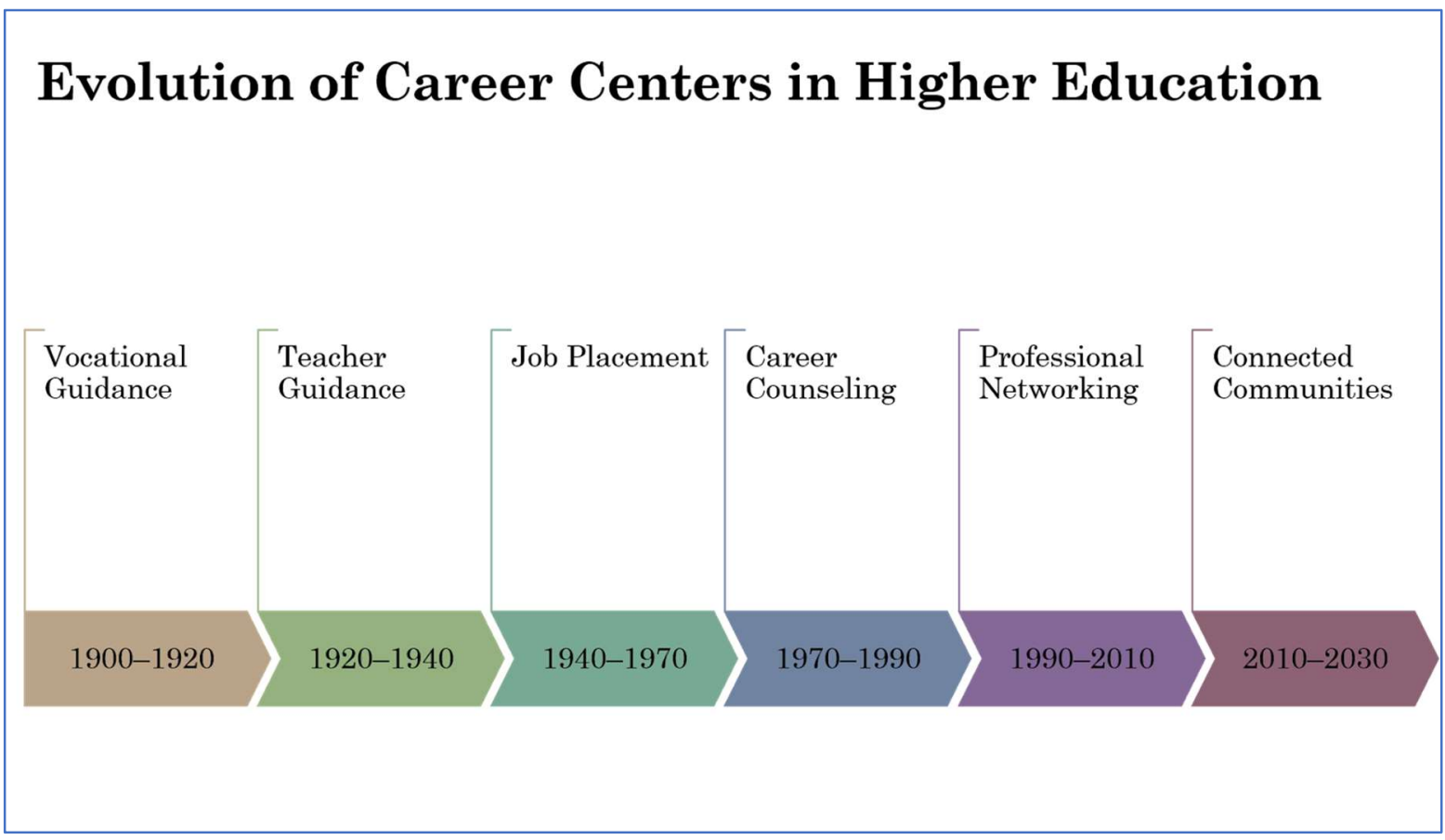

The workforce development system is a federal system. State and local boards steer the AJC system, providing local agencies with a great deal of authority and flexibility (Haskins \& Margolis, 2015). Local steering bodies can be useful to an AJC to help it shift its service delivery model to serve college students and the public while meeting WIOA mandates. Moreover, research shows that students who engaged with their college/university career center experienced higher rates of obtaining full-time employment (Career Services, 2010). The structure of college/university career centers is important in determining whether it has merit to serve as an AJC. For example, there are two main structures to college/university career centers: centralized and decentralized (Schaub, 2012). A centralized career center acts as a hub or central location for all career services and can serve job seekers/students across majors, while a decentralized system may have multiple centers on campus, and the centers may specialize in 
specific majors or industries (Schaub, 2012). Since AJCs serve job seekers across sectors, a centralized college/university career center is likely to be most compatible with the AJC model.

Based on the above timeline of career services in higher education, AJCs seem to combine elements from each era from 1900-1990 and touch upon components of higher education's career service models from its last two evolutions. As organizations like the National Association of Colleges and Employers (NACE) establish standards for measuring success that can be used nation-wide, college/university career services that are often hesitant to collect employment or placement data should reconsider due to the benefits of taking a leading role in collecting placement data. College/university career centers in higher education can help lead institution-wide discussions about student readiness for employment (Dey \& Cruzvergara, 2015). Due to high student tuition and the economic climate, higher education faces pressure from stakeholders to be more career focused (Despeaux, Knotts, \& Schiff, 2014). This pressure aligns well with WIOA's overall goals and objectives regarding employment outcomes. Incorporating a WIOA program into colleges and universities is important, because as colleges/universities report outcomes, student employment may have an impact on admissions and an institution's college report card (LaRose, 2015).

If college/university career centers shift their focus to include placement data as part of their metrics of success, AJC methodologies for such data collection may prove to be helpful to colleges and universities. As college career centers explore new approaches to career services, like professional networking and connecting communities, AJCs may find college/university career center approaches and methodologies helpful. 
18| Pag e 


\section{METHODOLOGY}

This research focuses on one of three Key Performance Indicators (KPIs) of the Workforce Innovation and Opportunity Act (WIOA). The KPI to be studied pertains to job seeker enrollment. Two methodologies were applied to analyze whether career services for the adult and dislocated worker population of the WIOA can be leveraged to serve a college student population while meeting WIOA's enrollment goals. To answer this question, data from nonexperimental and quasi-experimental research methodologies were analyzed from Ohlone Community College (Ohlone) located in the greater Silicon Valley in California and the Alameda County Workforce Development Board (ACWDB).

\section{Non-experimental}

The first step is to determine whether there is an eligible population of college students at Ohlone to satisfy WIOA contract requirements. Since these data collectively are not typically recorded or tracked by colleges/universities, an after-only survey of Ohlone students was conducted to assess whether the targeted populations exist within the college. A survey of Ohlone's 7,102 students was conducted by the Ohlone College Tri-Cities Career Center using a Survey Monkey instrument sent to student e-mails. The survey was administered between August $17^{\text {th }}, 2017$ to September $6^{\text {th }}, 2017$. The survey received responses from 3,553 students, meaning that more than $50 \%$ of the survey recipients responded.

Anonymized results from the Ohlone 2017 Job \& Internship survey data were collected from Ohlone. The results were analyzed to determine whether enough Ohlone students are eligible for participation in the WIOA program. A copy of the Ohlone College survey instrument can be found in Appendix A. 


\section{Quasi-experimental:}

The results from the after-only survey established whether the WIOA targeted populations exist at a college campus, a critical element to answering the research question, but it does not answer whether an AJC can successfully enroll job seekers into the program while meeting WIOA enrollment objectives.

To answer this question, a time-series design was implemented to analyze whether Ohlone's interventions of targeting WIOA eligible students for a series of months to engage them with the career center resulted in student enrollment into the program. These data compare Ohlone's enrollment figures from fiscal year (FY) 2016/2017 to the current FY 2017/2018. The interventions were applied during the $2017 / 2018$ FY and were not in place during the 2016/2017 FY. A comparative analysis between both years shows whether Ohlone's interventions were successful, and should provide enough insight into whether a WIOA program can be leveraged to serve college students while meeting WIOA enrollment mandates.

The time-series design data were tracked monthly from July 2016 to March 2018, with Ohlone interventions taking place monthly between September 2017 - March 2018.

\section{Figure 3: Time Series Design}

\begin{tabular}{|llllllllll}
\hline \multicolumn{7}{l}{ Time Series Design - Monthly } \\
R1 & O & O & O & O & O & O & O & O & O \\
R2 & O & XO & XO & XO & XO & XO & XO & XO & XO \\
\multicolumn{10}{l}{ Time-Series Design - Quarterly } \\
R1 & O & O & O & N/A & & & & \\
R2 & XO & XO & XO & N/A & & & & \\
\hline
\end{tabular}

R1 represents Ohlone's WIOA enrollments from the 016/2017 FY with no Ohlone intervention to enroll Ohlone students into the WIOA program. Most program enrollments occur 
during the first three quarters of each year. The O's represent observations of job seeker enrollment for three quarters from July 1, 2016, to March 31, 2017, into the WIOA program. Data were reviewed to determine the total number of Ohlone students who enrolled in the WIOA program on their own. R2 represents Ohlone's WIOA enrollments from the first three-quarters of the 2017/2018 FY (July 1, 2017, to March 31, 2018) with Ohlone interventions that consist of outreach and services to WIOA eligible students between September 1, 2017, to March 31, 2018. The Os represent monthly observations of student enrollment into the WIOA program. The Xs represent the months in which interventions were deployed that consists of targeted student outreach to WIOA eligible students. 
22 | P a g e 


\section{FINDINGS}

\section{Non-experimental: Ohlone College's 2017 Job \& Internship survey outcomes}

To determine if Ohlone's student population included WIOA eligible candidates, a survey was conducted to assess student demographics and their employment needs. The survey was submitted to 7,102 students enrolled during the Fall 2017 semester. High school students who were co-enrolled were not included in the survey research. Student responses were collected over two weeks through e-mail marketing by Survey Monkey. At the completion of the survey collection period, 3,553 students had responded to the questionnair, a response rate of $50 \%$.

To determine whether Ohlone's student population included WIOA eligible candidates, these data showcase results from the 2,431 students who stated that they were interested in services, and from the 1,310 student responders who indicated that they conducted a job search during the previous 12 months. Since the WIOA program focuses on job placement, the data in this research summarizes responses from individuals interested in employment and those who sought employment. Responses from students who did not seek employment or were not interested in services are not included because they are not considered job seekers or part of the workforce, and therefore are not appropriate for the WIOA program. 


\section{Figure 4: Interest in Career Services}

If you are eligible to receive individualized job and internship placement services, will you like for us to reach out to you
regarding paid jobs and internships?

Answered: 3,553 Skipped: 0

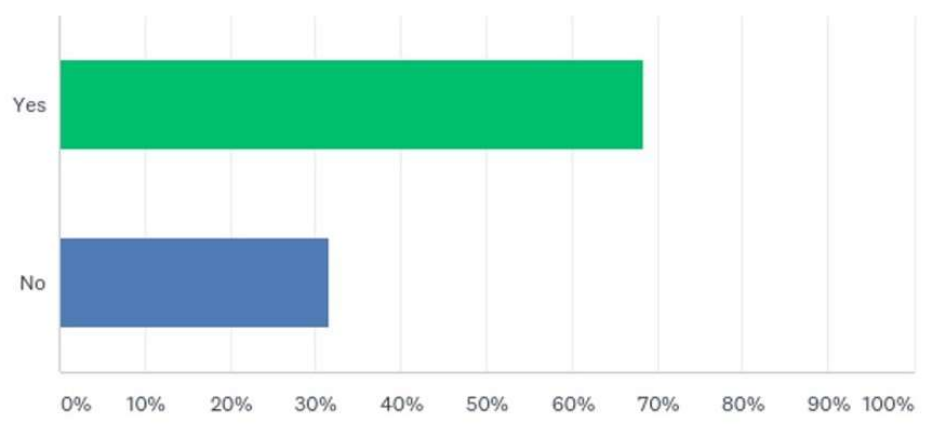

ANSWER CHOICES

RESPONSES

Yes

$68.42 \%$

2,431

No

$31.58 \%$

1,122

TOTAL

3,553

This figure is based on all 3,553 students who participated in the questionnaire. Approximately $68 \%$ of Ohlone students stated that they were interested in receiving placement support services. 


\section{Figure 5: Layoff}

Were you laid off from your last job?

Answered: 1,731 Skipped: 700

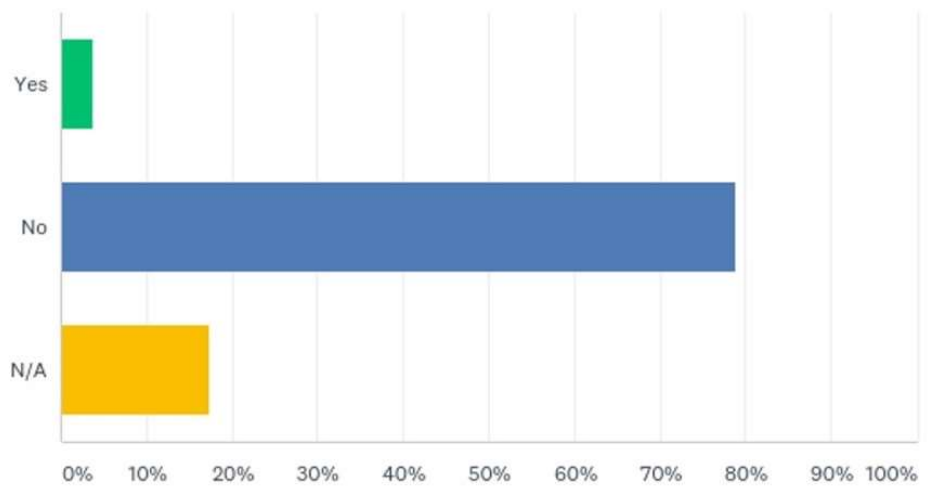

\section{ANSWER CHOICES}

Yes

No

N/A

TOTAL

\section{RESPONSES}

$3.76 \%$

65

$78.97 \%$

1,367

$17.27 \%$

299

1,731

This figure is based on the 2,431 students who stated that they were interested in receiving services. Nearly $4 \%$ of Ohlone students interested in receiving support services stated that they were laid off from their last job, an indicator of eligibility for placement support services. 


\section{Figure 6: Unemployment Status}

Please select the response that best describes your employment situation:

Answered: 1,731 Skipped: 700

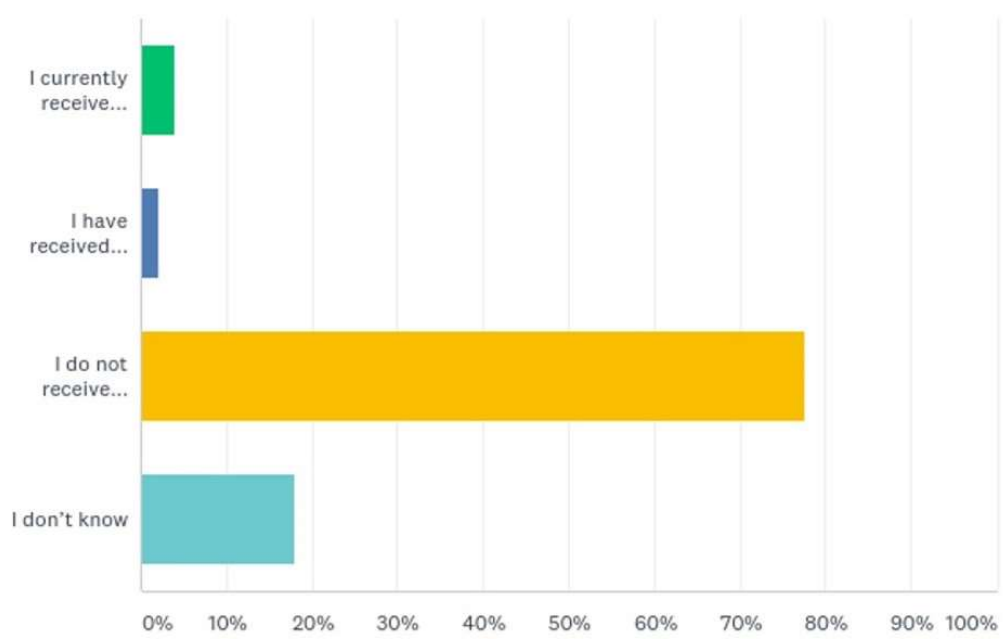

\section{ANSWER CHOICES}

RESPONSES

I currently receive Unemployment

$3.93 \%$

I have received unemployment in the past three years

$2.08 \%$

I do not receive unemployment

$77.70 \%$

I don't know

$17.91 \%$

310

Total Respondents: 1,731

This figure is based on the 2,431 students who stated that they were interested in receiving services. Nearly $4 \%$ of Ohlone students interested in receiving support services stated that they were receiving unemployment or received unemployment during the past three years, an indicator of eligibility for placement support services. 


\section{Figure 7: Employment Opportunities Sought}

Select the opportunities you attempted to obtain (select all that apply)

Answered: 1,303 Skipped: 7

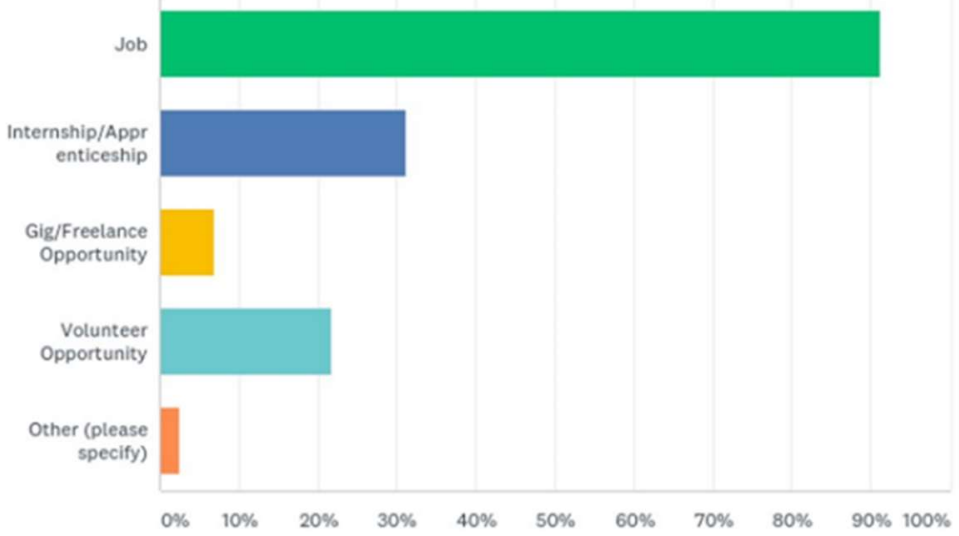

\begin{tabular}{|c|c|c|}
\hline ANSWER CHOICES & RESPOI & \\
\hline Job & $91.25 \%$ & 1,189 \\
\hline Internship/Apprenticeship & $31.16 \%$ & 406 \\
\hline Gig/Freelance Opportunity & $6.91 \%$ & 90 \\
\hline Volunteer Opportunity & $21.80 \%$ & 284 \\
\hline Other (please specify) & $2.61 \%$ & 34 \\
\hline
\end{tabular}

This figure is based on the 1,310 students who conducted a job search during the past 12 months. Approximately $91 \%$ of Ohlone students who conducted a job search stated that they sought out regular employment (job), an indicator of eligibility for placement support services. 


\section{Figure 8: Job/Internship Obtainment}

Between July 1, 2016, to June 30, 2017, did you obtain any type of job or internship (paid or unpaid)?

Answered: 1,296 Skipped: 14

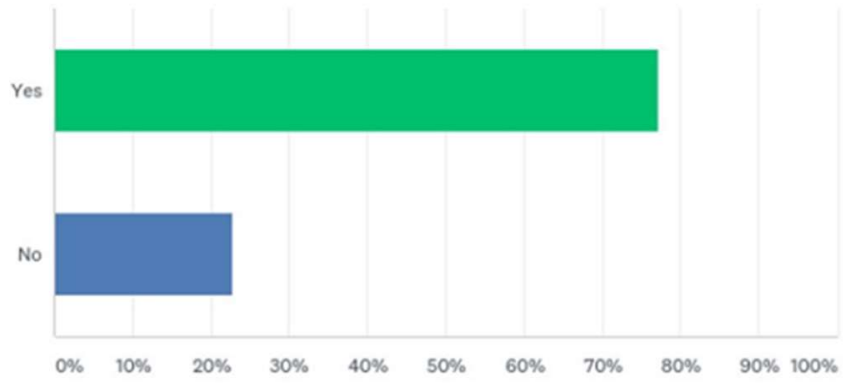

\begin{tabular}{|c|c|c|}
\hline ANSWER CHOICES & RESPON & \\
\hline Yes & $77.24 \%$ & 1,001 \\
\hline No & $22.76 \%$ & 295 \\
\hline TOTAL & & 1,296 \\
\hline
\end{tabular}

This figure is based on the 1,310 students who conducted a job search during the past 12 months.

Nearly $23 \%$ of Ohlone students who conducted a job search stated that they were unsuccessful. 


\section{Figure 9: Current Employment Status}

Are you currently employed?

Answered: 1,184 Skipped: 126

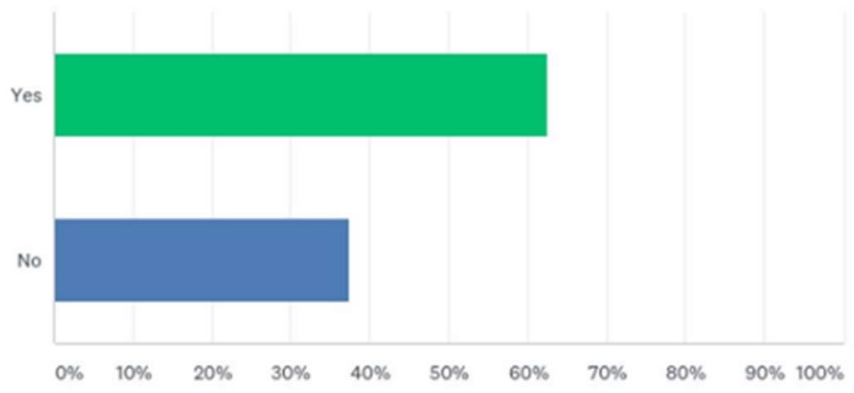

\begin{tabular}{|c|c|c|}
\hline ANSWER CHOICES & RESPON & \\
\hline Yes & $62.50 \%$ & 740 \\
\hline No & $37.50 \%$ & 444 \\
\hline TOTAL & & 1,184 \\
\hline
\end{tabular}

This figure is based on the 1,310 students who conducted a job search during the past 12 months. Approximately $38 \%$ of Ohlone students who conducted a job search stated that they were unemployed at the time of the survey. 


\section{Figure 10: Financial Aid}

Do you currently receive financial aid or scholarships?

Answered: 1,599 Skipped: 832

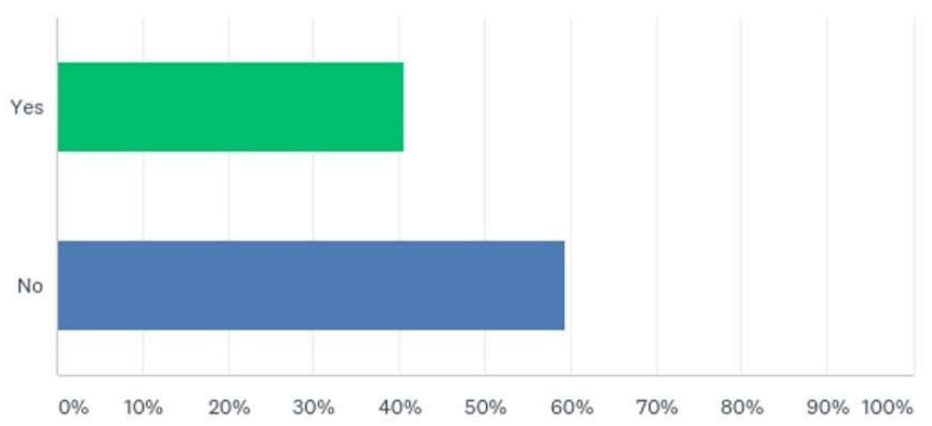

\begin{tabular}{|c|c|c|}
\hline ANSWER CHOICES & RESPOI & \\
\hline Yes & $40.65 \%$ & 650 \\
\hline No & $59.35 \%$ & 949 \\
\hline TOTAL & & 1,599 \\
\hline
\end{tabular}

This figure is based on the 2,431 students who stated that they were interested in receiving services. Nearly $41 \%$ of Ohlone students who were interested in receiving services were recipients of financial aid, a potential indicator of eligibility for placement support services. 


\section{Figure 11: Veteran Status}

Are you a Veteran?

Answered: 1,601 Skipped: 830

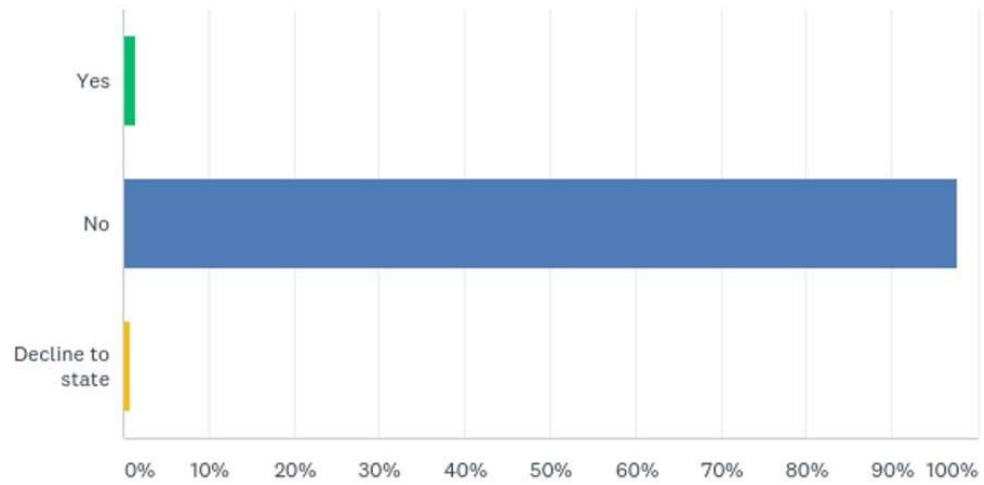

ANSWER CHOICES

Yes

No

Decline to state

TOTAL

\section{RESPONSES}

$1.37 \%$

$97.75 \%$

1,565

$0.87 \%$

This figure is based on the 2,431 students who stated they were interested in receiving services. Approximately $1 \%$ of Ohlone students who were interested in receiving services stated that they were veterans, an indicator of eligibility for placement support services. 


\section{Figure 12: Disability Status}

Are you an individual with a disability (physical, mental health, learning, etc.)?

Answered: 1,605 Skipped: 826

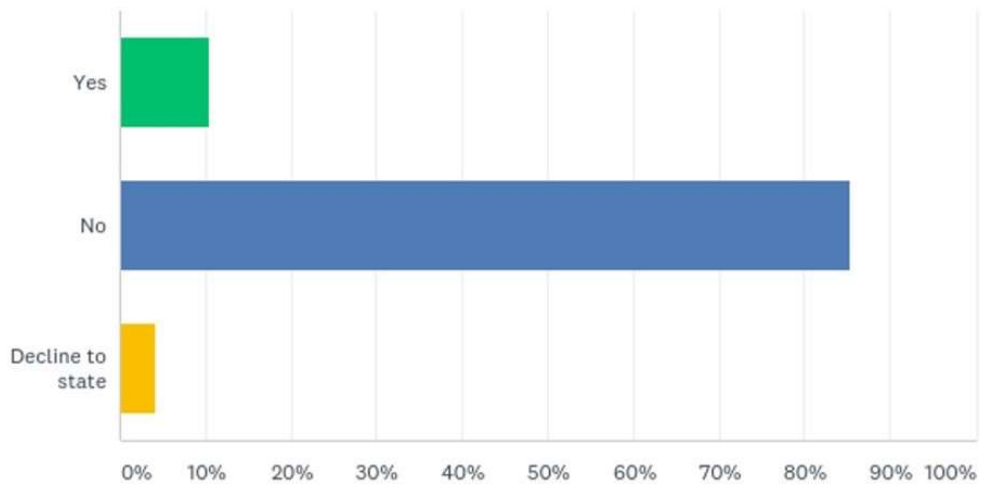

\section{ANSWER CHOICES}

Yes

No

Decline to state

\section{RESPONSES}

$10.47 \%$ 168

$85.42 \%$ 1,371

$4.11 \%$ 66

This figure is based on the 2,431 students who stated that they were interested in receiving services. Approximately $10 \%$ of Ohlone students who were interested in receiving services stated that they were an individual with a disability, an indicator of eligibility for placement support services. 


\section{Figure 13: Public Assistance}

Do you currently receive public assistance (Social Security Insurance (SSI), Temporary Assistance for Needy Families (TANF), General Assistance (GA), Food Stamps)?

Answered: $1,731 \quad$ Skipped: 700

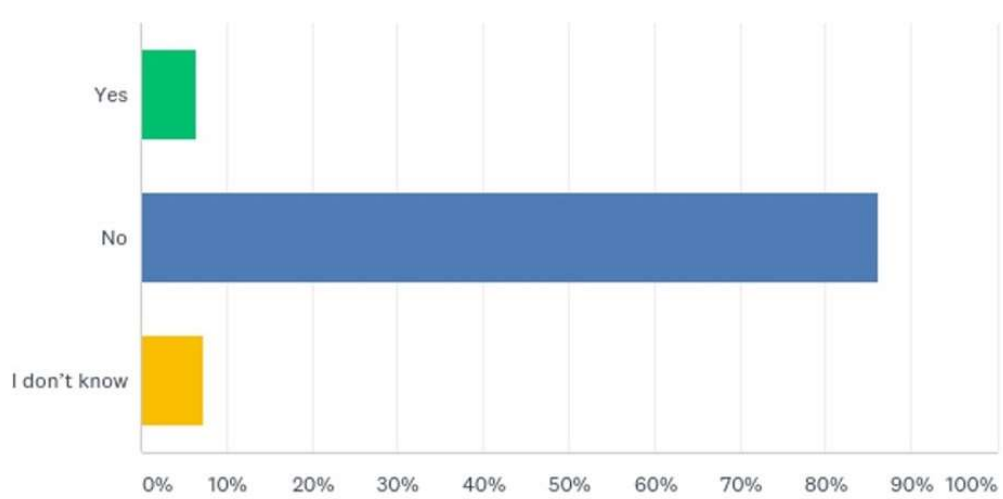

\begin{tabular}{|c|c|c|}
\hline ANSWER CHOICES & \multicolumn{2}{|c|}{ RESPONSES } \\
\hline Yes & $6.59 \%$ & 114 \\
\hline No & $86.14 \%$ & 1,491 \\
\hline I don't know & $7.28 \%$ & 126 \\
\hline TOTAL & & 1,731 \\
\hline
\end{tabular}

This figure is based on the 2,431 students who stated that they were interested in receiving services. Nearly $7 \%$ of Ohlone students who were interested in receiving services stated that they were recipients of public assistance, an indicator of eligibility for placement support services. 


\section{Figure 14: Residency}

Please select an option below:

Answered: 1,731 Skipped: 700

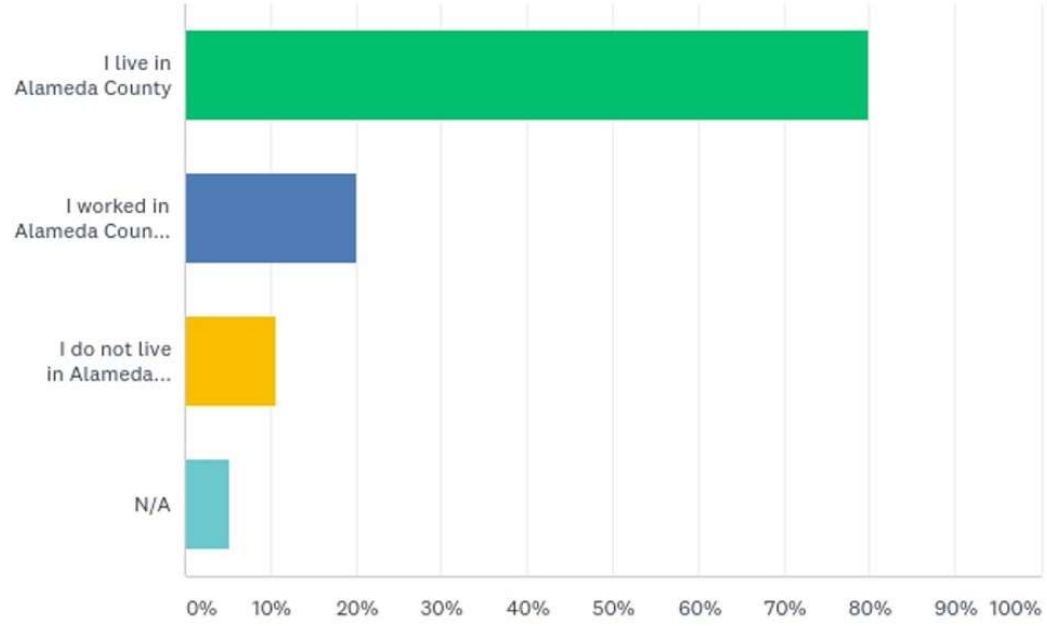

\section{ANSWER CHOICES}

RESPONSES

$79.84 \%$

I live in Alameda County

1,382

I worked in Alameda County during the past six months

$20.05 \% \quad 347$

I do not live in Alameda County and I have not worked in Alameda County during

$10.63 \% \quad 184$ the past six months.

$\mathrm{N} / \mathrm{A}$

$5.31 \% \quad 92$

Total Respondents: 1,731

This figure is based on the 2,431 students who stated they were interested in receiving services.

Nearly $80 \%$ of Ohlone students who were interested in receiving services stated that they lived in Alameda County, an indicator of eligibility for placement support services. 


\section{Figure 15: Work Authorization}

Are you eligible to work in the United States?

Answered: 1,731 Skipped: 700

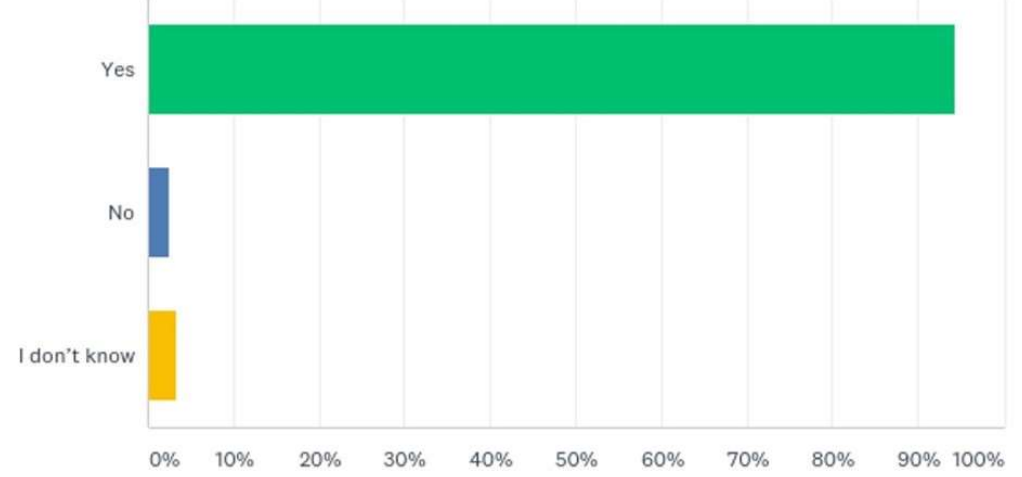

\begin{tabular}{|c|c|c|}
\hline ANSWER CHOICES & RESPON & \\
\hline Yes & $94.28 \%$ & 1,632 \\
\hline No & $2.43 \%$ & 42 \\
\hline I don't know & $3.29 \%$ & 57 \\
\hline TOTAL & & 1,731 \\
\hline
\end{tabular}

This figure is based on the 2,431 students who stated that they were interested in receiving services. Approximately $94 \%$ of Ohlone students who were interested in receiving services stated that they were eligible to work in the United States, an indicator of eligibility for placement support services. 


\section{Quasi-experimental: Ohlone College WIOA enrollment outcomes:}

This research explores whether career services for the adult and dislocated worker populations of the WIOA program can be leveraged to serve a college student population while meeting WIOA enrollment goals.

WIOA program enrollments take place between July to June each year. Most enrollments occur during the first three quarters. This research compares program enrollments during the first three-quarters of FY 2016/2017 and FY 2017/2018.

\section{Figure 16. Time Series Design}

\begin{tabular}{|c|c|c|c|c|c|c|c|c|c|}
\hline \multicolumn{10}{|c|}{ Time Series Design - Monthly } \\
\hline R1 & $\mathrm{O}$ & $\mathrm{O}$ & $\mathrm{O}$ & $\mathrm{O}$ & $\mathrm{O}$ & $\mathrm{O}$ & $\mathrm{O}$ & $\mathrm{O}$ & $\mathrm{O}$ \\
\hline $\mathrm{R} 2$ & $\mathrm{O}$ & $\mathrm{XO}$ & $\mathrm{XO}$ & $\mathrm{XO}$ & $\mathrm{XO}$ & $\mathrm{XO}$ & $\mathrm{XO}$ & $\mathrm{XO}$ & $\mathrm{XO}$ \\
\hline \multicolumn{10}{|c|}{ Time-Series Design - Quarterly } \\
\hline R1 & $\mathrm{O}$ & $\mathrm{O}$ & $\mathrm{O}$ & $\mathrm{N} / \mathrm{A}$ & & & & & \\
\hline $\mathrm{R} 2$ & $\mathrm{XO}$ & $\mathrm{XO}$ & $\mathrm{XO}$ & $\mathrm{N} / \mathrm{A}$ & & & & & \\
\hline
\end{tabular}

This research summarizes data from a time-series design. R1 indicates a control group of WIOA enrollees from FY 2016/2017 when no effort was made to enroll Ohlone students into the WIOA program. These data will serve as a baseline for WIOA enrollments. Ohlone student enrollments during R1 took place organically as students specifically sought employment and job placement support.

R2 indicates a quasi-experimental group of WIOA enrollees from FY 2017/2018 when interventions were made to enroll Ohlone students into the WIOA program. These data will 
provide insight into whether the interventions had an impact on Ohlone student enrollment. Data were evaluated on a monthly (Figure 17) and quarterly basis (Figure 18).

Figure 17. Ohlone College Time Series Design - Monthly

\begin{tabular}{|l|r|r|r|r|r|r|r|r|r|r|r|r|}
\hline \multicolumn{10}{|c|}{ Ohlone Student Enrollments into WIOA (Monthly) } \\
\hline Month & Jul & Aug & Sep & Oct & Nov & Dec & Jan & Feb & Mar & TOTAL \\
\hline FY 2016/2017 & 0 & 0 & 0 & 0 & 0 & 8 & 1 & 0 & 0 & $\mathbf{9}$ \\
\hline FY 2017/2018 & & 0 & 2 & 3 & 2 & 10 & 1 & 0 & 0 & 0 & $\mathbf{1 8}$ \\
\hline
\end{tabular}

Figure 18. Ohlone College Time Series Design - Quarterly

\begin{tabular}{|l|r|r|r|r|}
\hline \multicolumn{5}{|c|}{ Ohlone Student Enrollments into WIOA (Quarterly) } \\
\hline & & & & \\
Quarter & Q1 (Jul-Sep) & Q2 (Oct-Dec) & Q3 (Jan-Mar) & TOTAL \\
\hline FY 2016/2017 & 0 & 8 & 1 & 9 \\
\hline FY 2017/2018 & 5 & 13 & 0 & 18 \\
\hline
\end{tabular}




\begin{abstract}
ANALYSIS
This analysis will first outline the results of Ohlone College's 2017 Job \& Internship survey and then the results of its quasi-experimental design to enroll students into the WIOA
\end{abstract}

program.

\title{
Non-experimental: Ohlone College's 2017 Job \& Internship survey outcomes:
}

\section{Figure 19: Interest in Career Services}

If you are eligible to receive individualized job and internship placement services, will you like for us to reach out to you regarding paid jobs and internships?

Answered: 3,553 Skipped: 0

\begin{tabular}{|c|c|c|}
\hline ANSWER CHOICES & \multicolumn{2}{|c|}{ RESPONSES } \\
\hline Yes & $68.42 \%$ & 2,431 \\
\hline No & $31.58 \%$ & 1,122 \\
\hline TOTAL & & 3,553 \\
\hline
\end{tabular}

Interest in Career Services: The outcomes from the Ohlone College 2017 Job \& Internship survey indicate that Ohlone students are eligible for the WIOA program. As shown in Figure 19, the results indicate that 2,431 students, or approximately $68 \%$ of those surveyed, stated that they were interested in receiving individualized placement services. This value is significantly greater than the 178 enrollments needed to satisfy the WIOA contract requirements. This indicates sufficient interest from Ohlone students to receive placement support using AJCC reesources. 


\section{Figure 20: Layoff}

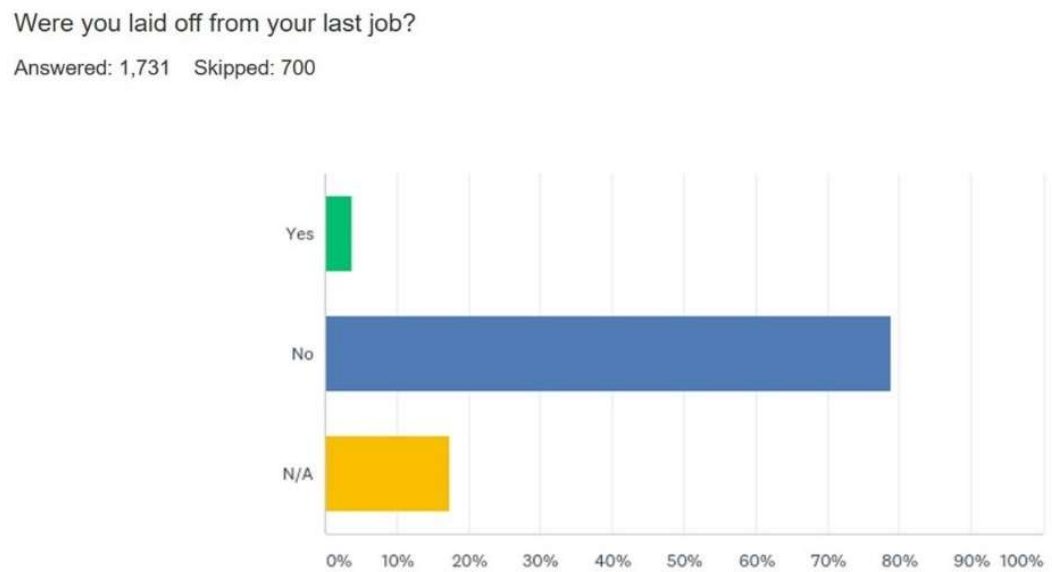

\begin{tabular}{l|lr}
\hline ANSWER CHOICES & RESPONSES & 65 \\
\hline YeS & $3.76 \%$ & 1,367 \\
\hline NO & $78.97 \%$ & 299 \\
\hline N/A & $17.27 \%$ & 1,731 \\
\hline TOTAL & & \\
\hline
\end{tabular}

\section{Figure 21: Unemployment Status}

Please select the response that best describes your employment situation:

Answered: 1,731 Skipped: 700

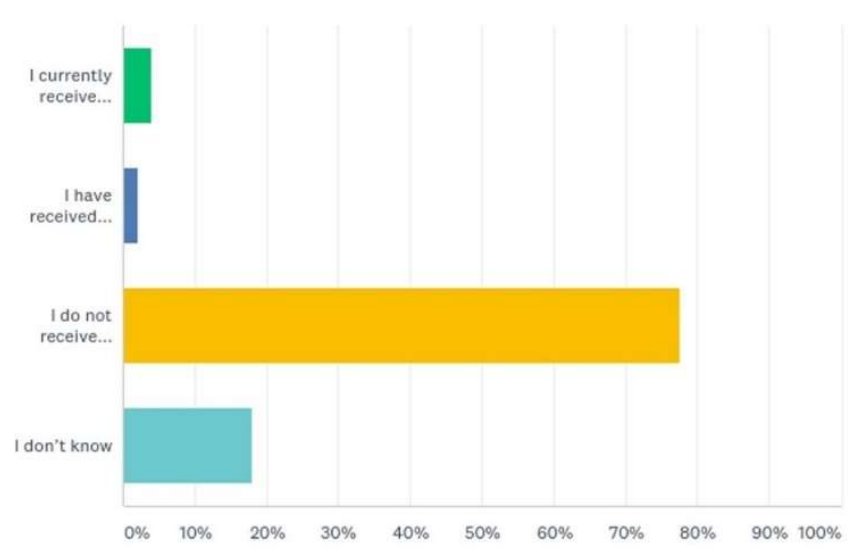

\begin{tabular}{l|c}
\hline ANSWER CHOICES & RESPONSES \\
\hline I currently receive Unemployment & $3.93 \%$ \\
\hline I have received unemployment in the past three years & $2.08 \%$ \\
\hline I do not receive unemployment & $77.70 \%$ \\
\hline I don't know & $17.91 \%$ \\
\hline Total Respondents: 1,731 & 310 \\
\hline
\end{tabular}

39 | P a g e 
Layoff \& Unemployment Status: The outcomes from the Ohlone College 2017 Job \& Internship survey indicate that Ohlone students experienced layoffs and unemployment. As shown in Figures 20 and 21, the results indicate that 65 students, or approximately $4 \%$ of those surveyed, stated that they were laid off from employment, and 68 students, or approximately $4 \%$ of those surveyed, stated that they were receiving unemployment. This value is fewer than the 97 enrollments needed to satisfy the WIOA program contract. This indicates that if all 68 students receiving unemployment who were interested in services were eligible and enrolled in the WIOA program, then approximately $70 \%$ of the WIOA contract requirements can be satisfied by Ohlone students. It is likely that throughout the rest of the year more students will potentially enroll in the WIOA program if they are laid off or collect unemployment. This population component can also be met by enrolling candidates who are alumni, or by targeting non-student job seekers in the community. 


\section{Figure 22: Employment Opportunities Sought}
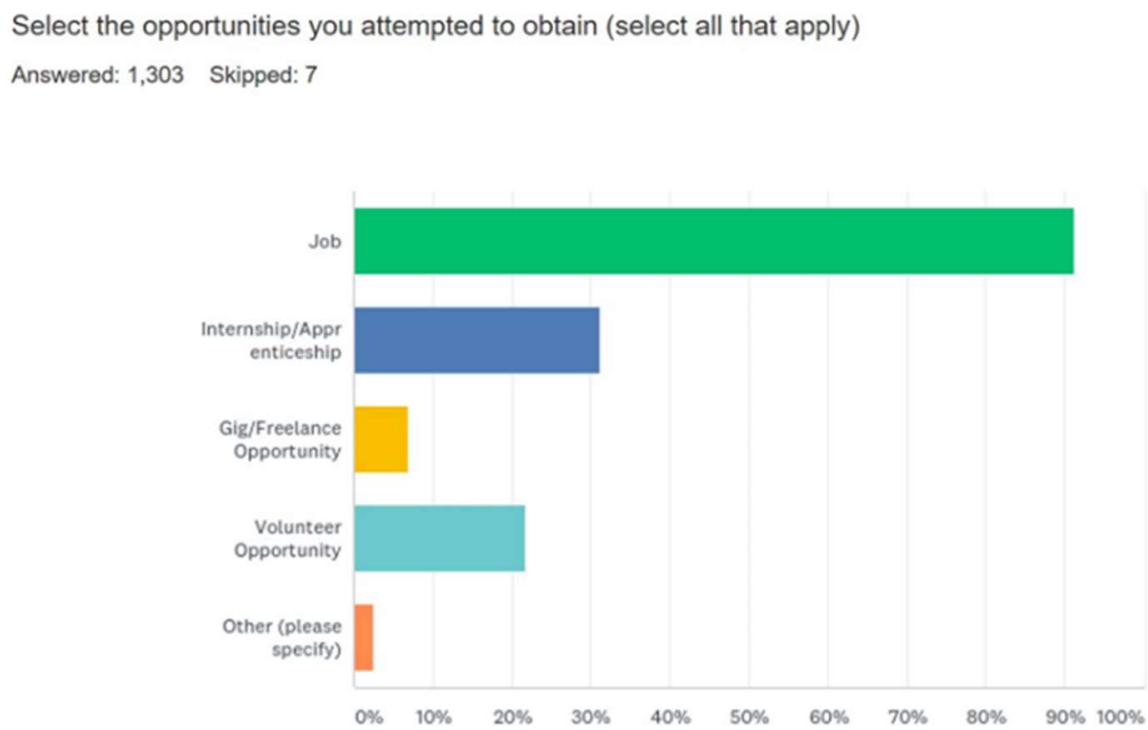

\begin{tabular}{|c|c|c|}
\hline ANSWER CHOICES & \multicolumn{2}{|c|}{ RESPONSES } \\
\hline Job & $91.25 \%$ & 1,189 \\
\hline Internship/Apprenticeship & $31.16 \%$ & 406 \\
\hline Gig/Freelance Opportunity & $6.91 \%$ & 90 \\
\hline Volunteer Opportunity & $21.80 \%$ & 284 \\
\hline Other (please specify) & $2.61 \%$ & 34 \\
\hline
\end{tabular}

Total Respondents: 1,303

Employment Opportunities Sought: The outcomes from the Ohlone College 2017 Job \& Internship survey indicate that Ohlone students sought regular employment (job). As shown in Figures 22 , the results indicate that 1,189 students, or approximately $91 \%$ of those surveyed, stated that they sought a job. This value indicates that the great majority of students sought conventional employment opportunities, making them eligible and appropriate for the WIOA program. This value more than satisfies the 178 enrollments needed to satisfy the WIOA contract requirements. 


\section{Figure 23: Job/Internship Obtainment}

Between July 1, 2016, to June 30, 2017, did you obtain any type of job or internship (paid or unpaid)?

Answered: 1,296 Skipped: 14

Yes

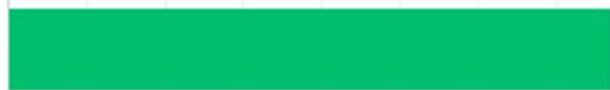

No

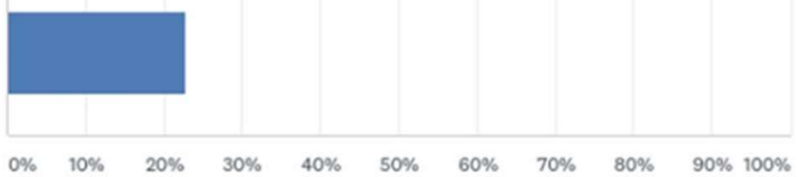

\begin{tabular}{|c|c|c|}
\hline ANSWER CHOICES & RESPON & \\
\hline Yes & $77.24 \%$ & 1,001 \\
\hline No & $22.76 \%$ & 295 \\
\hline TOTAL & & 1,296 \\
\hline
\end{tabular}

Figure 24: Current Employment Status

Are you currently employed?

Answered: 1,184 Skipped: 126

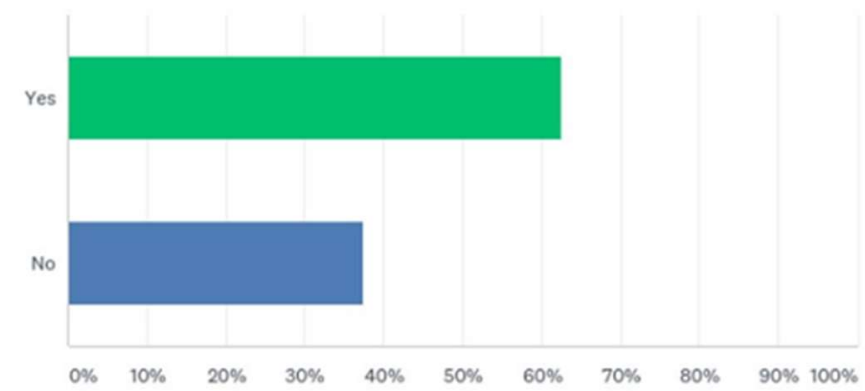

ANSWER CHOICES

RESPONSES

Yes

$62.50 \%$

740

No

$37.50 \%$

444

TOTAL 
Job/Internship Obtainment \& Current Employment Status: The outcomes from the Ohlone College 2017 Job \& Internship survey indicate that not all Ohlone students who sought employment were successful. Figures 23 and 24 indicate that 295 students, nearly $23 \%$, were not successful in their job search, and 444 students, or nearly $38 \%$, were unemployed at the time of the survey. Despite a healthy economy with low unemployment, a high ratio of student job seekers did not obtain employment. This indicates that services are not only of interest to students, but that career service support may be necessary.

\section{Figure 25: Financial Aid}

Do you currently receive financial aid or scholarships?

Answered: 1,599 Skipped: 832

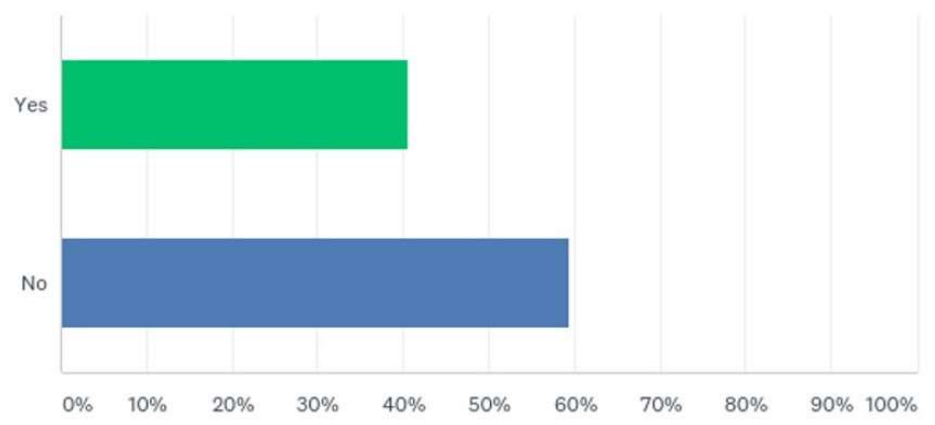

\section{ANSWER CHOICES}

Yes

No

TOTAL

\section{RESPONSES}

$40.65 \%$

$59.35 \%$ 


\section{Figure 26: Veteran Status}

Are you a Veteran?

Answered: 1,601 Skipped: 830

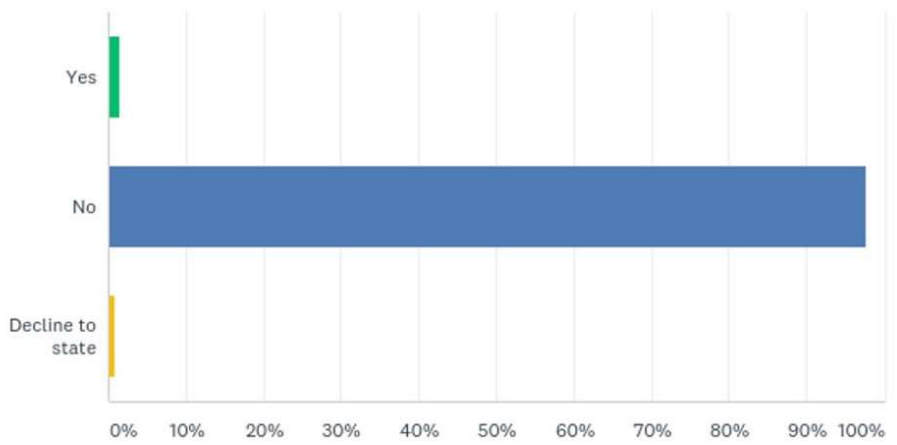

\begin{tabular}{|c|c|c|}
\hline ANSWER CHOICES & RESPON & \\
\hline Yes & $1.37 \%$ & 22 \\
\hline No & $97.75 \%$ & 1,565 \\
\hline Decline to state & $0.87 \%$ & 14 \\
\hline TOTAL & & 1,601 \\
\hline
\end{tabular}

\section{Figure 27: Disability Status}

Are you an individual with a disability (physical, mental health, learning, etc.)?

Answered: 1,605 Skipped: 826

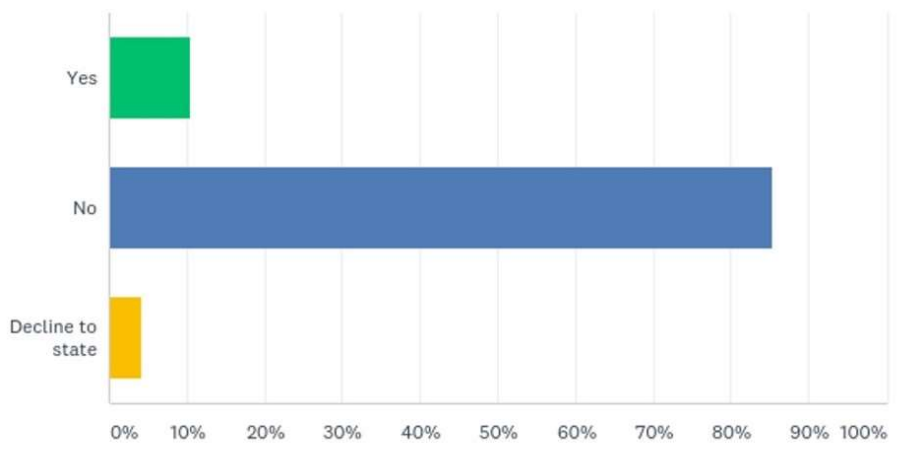

\begin{tabular}{|c|c|c|}
\hline ANSWER CHOICES & RESPONSES & \\
\hline Yes & $10.47 \%$ & 168 \\
\hline No & $85.42 \%$ & 1,371 \\
\hline Decline to state & $4.11 \%$ & 66 \\
\hline TOTAL & & 1,605 \\
\hline
\end{tabular}




\section{Figure 28: Public Assistance Status}

Do you currently receive public assistance (Social Security Insurance (SSI), Temporary Assistance for Needy Families (TANF), General Assistance (GA), Food Stamps)?

Answered: 1,731 Skipped: 700

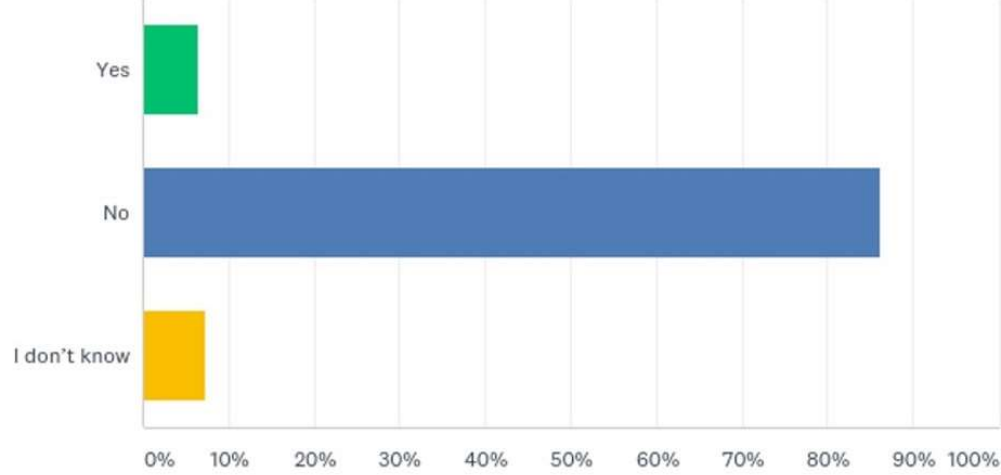

\section{ANSWER CHOICES}

Yes

No

I don't know

\section{RESPONSES}

$6.59 \%$

$86.14 \%$

$7.28 \%$

TOTAL

Financial Aid, Veteran, Disability, and Public Assistance Status: The outcomes from the Ohlone College 2017 Job \& Internship survey indicate that many Ohlone students receive financial aid, are veterans, individuals with disabilities and/or receive public assistance. These populations are considered priority populations and are required populations to target for services as mandated by the WIOA contract requirements. Figures 25-28 indicate that 650 students, nearly $41 \%$, received financial aid, a potential indicator of low-income status. Twenty-two, or nearly 1\%, are veterans, while 168 , approximately $10 \%$, self-identify as being an individual with a disability, and 114 , nearly $7 \%$, receive public assistance. These values are significantly greater than the 41 enrollments needed to satisfy the priority population expectation mandated by the WIOA contract requirements. 


\section{Figure 29: Residency}

Please select an option below:

Answered: 1,731 Skipped: 700

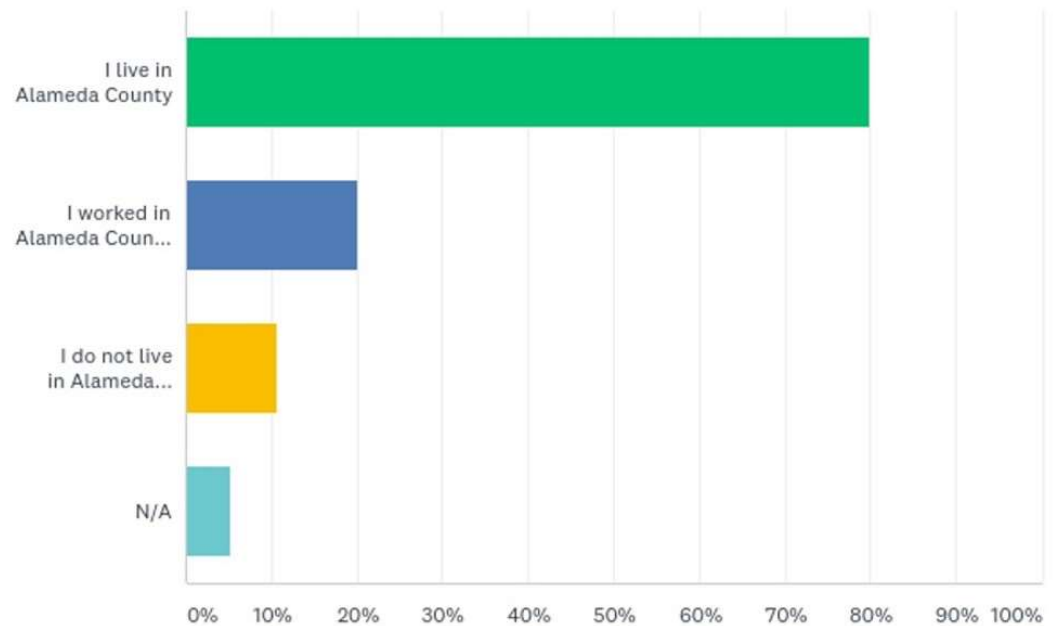

ANSWER CHOICES

RESPONSES

$79.84 \%$

I live in Alameda County

1,382

I worked in Alameda County during the past six months

$20.05 \% \quad 347$

I do not live in Alameda County and I have not worked in Alameda County during $10.63 \% \quad 184$ the past six months.

N/A

Total Respondents: 1,731 


\section{Figure 30: Work Authorization}

Are you eligible to work in the United States?

Answered: 1,731 Skipped: 700

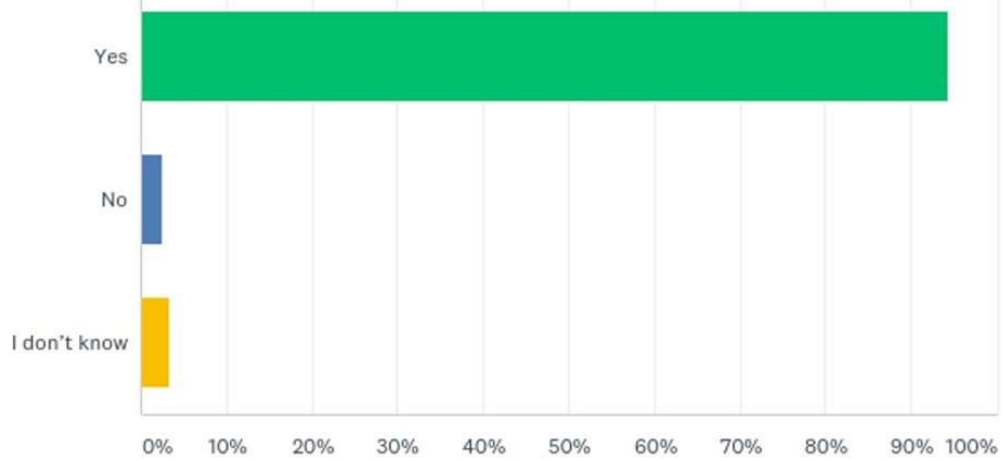

\begin{tabular}{|c|c|c|}
\hline ANSWER CHOICES & RESPON & \\
\hline Yes & $94.28 \%$ & 1,632 \\
\hline No & $2.43 \%$ & 42 \\
\hline I don't know & $3.29 \%$ & 57 \\
\hline TOTAL & & 1,731 \\
\hline
\end{tabular}

Residency \& Work Authorization: The outcomes from the Ohlone College 2017 Job \& Internship survey indicate that the great majority of Ohlone students reside in Alameda County and are authorized to work in the United States, and both are eligibility requirements mandated by the WIOA contract requirements. Figures 29 and 30 indicate that 1,382 students, nearly $80 \%$, live in Alameda County, and 1,632, approximately 94\%, are authorized to work in the United States. These values are significantly greater than the 178 enrollments needed to satisfy the WIOA contract requirements.

The outcomes from the Ohlone College 2017 Job \& Internship survey indicate that most enrollments can be satisfied by targeting Ohlone students to meet WIOA contract requirements. 


\section{Quasi-experimental: Ohlone College WIOA enrollment outcomes:}

The Ohlone College 2017 Job \& Internship survey shows that the populations exist at Ohlone to meet WIOA contract requirements. This research reviews whether interventions to enroll students in the program were successful. Enrolling Ohlone students into the WIOA program positions the career center to serve both community members and students while meeting WIOA contract requirements. As shown in Figure 31, R1 indicates a control group of Ohlone WIOA enrolled students from the 2016/2017 FY, when minimal to no interventions were made to enroll students into the WIOA program. Student enrollments occurred organically as students learned about the WIOA program or happened to come to the career center office. R2 represents the quasi-experimental group of Ohlone students who enrolled in the WIOA program during the 2017/2018 FY when interventions were made to enroll Ohlone students into the WIOA program. The time-series design reviews the first nine months of each year, during which most enrollments are made for the WIOA program.

\section{Figure 31: Time Series Design}

\begin{tabular}{|c|c|c|c|c|c|c|c|c|c|}
\hline \multicolumn{10}{|c|}{ Time Series Design - Monthly } \\
\hline R1 & $\mathrm{O}$ & $\mathrm{O}$ & $\mathrm{O}$ & $\mathrm{O}$ & $\mathrm{O}$ & $\mathrm{O}$ & $\mathrm{O}$ & $\mathrm{O}$ & $\mathrm{O}$ \\
\hline $\mathrm{R} 2$ & $\mathrm{O}$ & $\mathrm{XO}$ & $\mathrm{XO}$ & $\mathrm{XO}$ & $\mathrm{XO}$ & $\mathrm{XO}$ & $\mathrm{XO}$ & $\mathrm{XO}$ & $\mathrm{XO}$ \\
\hline \multicolumn{10}{|c|}{ Time-Series Design - Quarterly } \\
\hline R1 & $\mathrm{O}$ & $\mathrm{O}$ & $\mathrm{O}$ & N/A & & & & & \\
\hline $\mathrm{R} 2$ & $\mathrm{XO}$ & $\mathrm{XO}$ & $\mathrm{XO}$ & $\mathrm{N} / \mathrm{A}$ & & & & & \\
\hline
\end{tabular}

As outlined in Figure 32, during the 2016/2017 FY, nine students enrolled in the WIOA program organically. During the 2017/2018 FY, Ohlone intervened and provided targeted student outreach to promote career services and the WIOA program. During the 2017/2018 FY, 
exactly 18 students enrolled in the WIOA program, twice the number from the year prior, a $100 \%$ increase. At the time of this research, 14 additional students were pending enrollment. When processed, total Ohlone student enrollments can be 32 , a $255 \%$ increase and nearly $18 \%$ of the total 178 enrollments mandated by the WIOA contract requirements.

Figure 32: Ohlone College Time Series Design - Monthly

\begin{tabular}{|l|l|r|r|r|r|r|r|r|r|r|r|r|}
\hline \multicolumn{10}{|c|}{ Ohlone Student Enrollments into WIOA (Monthly) } \\
\hline Month & Jul & Aug & Sep & Oct & Nov & Dec & Jan & Feb & Mar & TOTAL \\
\hline FY 2016/2017 & 0 & 0 & 0 & 0 & 0 & 8 & 1 & 0 & 0 & $\mathbf{9}$ \\
\hline FY 2017/2018 & & 0 & 2 & 3 & 2 & 10 & 1 & 0 & 0 & 0 & $\mathbf{1 8}$ \\
\hline
\end{tabular}

Interventions: Ohlone deployed a series of interventions to attract and enroll students into the WIOA program. Interventions included hosting periodic student orientations, student drop-in counseling appoints twice a week, student-friendly jobs fairs, employer information sessions and panel discussions, student-focused recruiting events targeting part-time and seasonal employment, fieldtrips to employer campuses to learn about job and internship opportunities, student-friendly career development workshops, social media marketing on LinkedIn, Facebook, and Twitter, deploying a new Career Services Management (CSM) system, classroom presentations, faculty presentations, administrator collaborations, reaching across departments and divisions to engage staff, student email marketing, employer field trips, deploying a mentoring program, and integration with the financial aid department to coordinate the Job Location Development (JLD) program through Work-Study, a funding source and program available to all institutions that receive federal work-study funding.

Program Logic Models (PLMs) were created to record student engagement with the Career Center to determine outcomes of interventions. Figure 33 showcases the Outreach \& 
Enrollment inputs, activities, outputs, and outcomes. This team was focused on attracting students to the career center to solicit interest in joining the WIOA program. Figure 34 showcases Career Development inputs, activities, outputs and outcomes. This team was focused on preparing students for the workforce. Preparation includes career and major exploration, employment and internship preparation, and connecting students to additional support services, if needed, like transportation, housing, and more. Figure 34 showcases Employer Engagement inputs, activities, outputs, and outcomes. This team was focused on attracting employers to campus to connect them to student job seekers and non-student job seekers, with an emphasis on integrating Ohlone students into the employer connection experience.

These new interventions resulted in 1,838 non-unique student engagements with the career center during the first three quarters of the WIOA fiscal year (July 1, 2017 - March 31, 2018) through various events and activities. This indicates that in addition to 18 students formally enrolling into the WIOA program, this new approach resulted in nearly 2,000 student engagements, providing students with various access points and opportunities to connect with the career center, regardless of their WIOA enrollment status. 
Figure 33: PLM Outreach \& Enrollment

\begin{tabular}{|c|c|c|c|c|}
\hline \multicolumn{5}{|c|}{ Program Logic Model: Outreach \& Enrollment } \\
\hline Inputs & Activities & Outputs & Outcomes (Tier 1) & Outcomes (Tier 2) \\
\hline $\begin{array}{l}\text { Time (Hours) } \\
\text { Dept Expenses }\end{array}$ & $\begin{array}{l}\text { Student meetings } \\
\text { Community Meetings } \\
\text { Presentation/Workshops } \\
\text { Conference/Summit } \\
\text { Other Event Planning } \\
\text { Luncheons/Banquets } \\
\text { Media/Press } \\
\text { Training } \\
\text { Cold Calling } \\
\text { Email Blasts } \\
\text { R\&D Activities } \\
\text { Curriculum/Content Development } \\
\text { Fiscal Management }\end{array}$ & $\begin{array}{l}\# \text { of Orientation } \\
\# \text { of Workshops } \\
\# \text { of traffic } \\
\# \text { of orientation attendees } \\
\# \text { of workshop attendees } \\
\# \text { of event attendees }\end{array}$ & $\begin{array}{l}\text { \#Applications Received } \\
\text { \#Applications Processed }\end{array}$ & $\begin{array}{l}\text { \# of Adult Priority } \\
\text { Enrollments } \\
\text { \# of Adult Non Priority } \\
\text { Enrollments } \\
\text { \# of Dislocated Worker } \\
\text { Enrollments } \\
\text { \# of student } \\
\text { enrollments } \\
\# \text { of students } \\
\text { processed }\end{array}$ \\
\hline
\end{tabular}

\section{Figure 34: PLM Career Development}

\begin{tabular}{|c|c|c|c|c|}
\hline \multicolumn{5}{|c|}{ Program Logic Model: Career Development } \\
\hline Inputs & Activities & Outputs & Outcomes (Tier 1 ) & Outcomes (Tier 2) \\
\hline $\begin{array}{l}\text { Time (hours) } \\
\text { Dept Expenses }\end{array}$ & $\begin{array}{l}\text { Meet with clients } \\
\text { Meet with community partners } \\
\text { Develop Curriculum } \\
\text { Case Management } \\
\text { Client/Student Outreach } \\
\text { Professional Development } \\
\text { Audit Preparation } \\
\text { Compile Reports }\end{array}$ & $\begin{array}{l}\# \text { of student/client appointments } \\
\# \text { of workshops } \\
\# \text { of attendees at workshops } \\
\# \text { of client in caseload } \\
\# \text { of approved ITA } \\
\# \text { of approved OJT } \\
\text { \# Mentor/Mentee matches } \\
\text { \# Mentorship event }\end{array}$ & $\begin{array}{l}\text { \# of ITA Completed } \\
\# \text { of OJT Completed } \\
\text { ITA/OJT spending } \\
\# \text { of client interviews } \\
\text { Mentee matches (students) } \\
\text { Mentor matches } \\
\% \text { Student Satisfaction Rate }\end{array}$ & Emloyment Outcomes \\
\hline
\end{tabular}


Figure 35: Employer Engagement

\section{Program Logic Model: Employer Engagement}

\begin{tabular}{|c|c|c|c|c|}
\hline Inputs & Activities & Outputs & Outcomes (Tier 1) & Outcomes (Tier 2) \\
\hline $\begin{array}{l}\text { Time (Hours) } \\
\text { Dept Expenses }\end{array}$ & $\begin{array}{l}\text { Employer consultation } \\
\text { Student meetings } \\
\text { Community meetings } \\
\text { Trainings } \\
\text { Mixers (attendee) } \\
\text { Mixers (tabling) } \\
\text { Luncheons/Banquets } \\
\text { Media/Press } \\
\text { Collateral creation } \\
\text { Presentaiton/Workshop } \\
\text { Creation } \\
\text { Conferences/Summits } \\
\text { Event planning } \\
\text { Marketing \& outreach } \\
\text { R\&D Activities }\end{array}$ & $\begin{array}{l}\text { \# of employer } \\
\text { orientations } \\
\text { \# of employer } \\
\text { representatives at } \\
\text { orientation } \\
\text { \# of new employer orgs } \\
\text { in database } \\
\text { \# of new employer reps } \\
\text { in database } \\
\text { \# of job postings in } \\
\text { database } \\
\text { \# of information } \\
\text { sessions } \\
\text { \# of employer reps at } \\
\text { info session } \\
\text { \# of students attending } \\
\text { information sessions } \\
\text { \# of job fairs } \\
\text { \# of employers } \\
\text { attending job fairs } \\
\text { \# of students attending } \\
\text { job fairs } \\
\text { \# of Drop-in Interviews } \\
\text { (DII) events } \\
\text { \# of DIl employers } \\
\text { \# of DIl employer reps } \\
\text { \# DIl student attendees } \\
\text { \# of approved OJTs } \\
\text { \# of Staffing services job } \\
\text { orders } \\
\text { \# of Employer tabling } \\
\text { events } \\
\text { \# Students visting } \\
\text { employer tabling } \\
\text { \# Employer reps for } \\
\text { employer tabling } \\
\text { \# Employer } \\
\text { workshops/trainings } \\
\text { \# Employer attendees } \\
\text { at workshop } \\
\text { \# Employers registered } \\
\text { as a Sponsor }\end{array}$ & $\begin{array}{l}\text { \# of interviews (OCI) } \\
\text { Amount of revenue } \\
\text { raised } \$ \$ \\
\% \text { student satisfaction } \\
\text { rate } \\
\text { \% employer satisfaction } \\
\text { rate }\end{array}$ & $\begin{array}{l}\text { \# of employment } \\
\text { outcomes }\end{array}$ \\
\hline
\end{tabular}




\section{CONCLUSION}

Having an institution of higher education serve as both a college/university career center and an AJC is unique. This research suggests that at Ohlone College, the student populations existed to satisfy WIOA contract requirements. Through intervention, student enrollment into the program was successful. Students benefitted from the WIOA program regardless of their enrollment status in the program because they could access an expanded menu of services that was developed to meet student employment and internship interests.

This approach can serve as a model for colleges and universities across the country by leveraging federal funds under the Workforce Innovation and Opportunity Act (WIOA). This research indicates that if colleges and universities applied for federal WIOA funding like Ohlone College to create or expand career services at their institution, it is possible and likely that career services for the adult and dislocated worker populations of the WIOA program can be provided to serve college students and community members while meeting WIOA's enrollment goals. By integrating college/university career services with community-centered WIO services, this research suggests that both career center models can be effective in meeting student and community career needs. WIOA is a feasible and unconventional funding source for college and university career centers and ought to be considered to augment the costs associated with student career development to provide expanded services to students and community job seekers. 
54 P a g e 


\section{APPENDEX A}

\section{Ohlone College's 2017 Job \& Internship Questionnaire}

Completing this questionnaire is completely confidential. We will not disclose individual answers outside of Ohlone College. Answering the questions below allows the Career Center to measure student employment rate, earnings, and employment eligibility for paid jobs and internships. Your completion of the survey indicates your willingness to participate. Feel free to record this information for your records.

Thank you for your participation.

1. If you are eligible to receive individualized job and internship placement services, will you like for us to reach out to you regarding paid jobs and internships?
a. Yes
b. No

2. Please complete the following:
a. Student ID\#
b. Email
c. Cell/Ph

3. Are you eligible to work in the United States?
a. Yes
b. No
c. I don't know

4. Please select an option below:
a. I live in Alameda County
b. I worked in Alameda County during the past six months
c. I do not live in Alameda County and I have not worked in Alameda County during the past six months
d. N/A

5. Were you laid off from your last job?
a. Yes
b. No
c. I don't know

6. Please select the response that best describes your employment situation:
a. I currently receive unemployment
b. I have received unemployment in the past three years
c. I am not currently receiving unemployment
d. I don't know 
7. Do you currently receive public assistance (Social Security Insurance (SSI), Temporary Assistance for Needy Families (TANF), General Assistance (GA), Food Stamps)?
a. Yes
b. No
c. I don't know

8. Between July 1, 2016, to June 30, 2017, did you attempt to obtain a job or internship?
a. Yes
b. No

9. Select the opportunities you attempted to obtain (select all that apply)
a. Job
b. Internship/Apprenticeship
c. Gig/Freelance Opportunity
d. Volunteer Opportunity
e. Other

10. Between July 1, 2016, to June 30, 2017, did you obtain any type of job or internship (paid or unpaid)?
a. Yes
b. No

11. What kind of job was it? Select all that apply.
a. Paid internship (intern, fellow, extern, apprentice)
b. Unpaid internship (intern, fellow, extern, apprentice)
c. Temporary/Seasonal
d. Student Assistant or Researcher
e. Contract (independent contractor, 1099 worker, freelancer)
f. Regular
g. Volunteer/Service Learning
h. Other
i. $\mathrm{N} / \mathrm{A}$

12. When you obtained your job or internship between July 1, 2016 - June 30, 2017, were you enrolled at Ohlone College?
a. Yes
b. No
c. N/A

13. Was your job or internship related to your academic major at Ohlone College?
a. Yes
b. No
c. I don't know

14. Was your employment on-campus or off-campus?
a. On-campus 
b. Off-campus

c. N/A

15. Did you typically work full-time (35+ hours a week) or part-time (under 35 hours a week)?
a. Full-time
b. Part-time
c. N/A

16. Estimate how much gross (before taxes) income you've earned from working between July 1, 2016, to June 30, 2017? Enter numeric values only. If you did not earn an income from work, enter 0 . If you have not yet earned income from work, enter 0. [Example: $\$ 15,350$ should be entered as 15350$]$

17. Approximately how much did/do you earn per hour? If you were/are not paid an hourly rate, skip to the next question. If you did not earn an income, enter 0 . Enter numeric values only (do not use dollar signs "\$" or commas ","). [Example: $\$ 11.25 / \mathrm{hr}$ should be entered as 11.25]

18. How did you learn of your job or internship? Check all that apply.
a. Ohlone College's Tri-Cities One-Stop Career Center
b. Ohlone College Job Fair
c. Ohlone College Job board
d. Ohlone College Recruitment Event
e. Ohlone College Tri-Cities One-Stop Career Center service or event not listed
f. Professor/Staff
g. Friends/family
h. Online job board, social media site, job fair, or another source NOT affiliated with Ohlone College
i. Other:
j. N/A

19. Please indicate your education level for the $2016 / 2017$ school year (the year that just ended).
a. I completed 0 units
b. I completed $1-29.5$ units
c. I completed $60+$ units
d. Other
e. I don't know

20. Select your Educational Program

[Drop-down menu appears here with a listing of all Ohlone College majors/programs]

21. Please select your educational goals (select all that apply):
a. To obtain a certificate 
b. To obtain an associate degree

c. To transfer to a four-year university

d. Other

22. Select the response that best reflects your exposure to the Ohlone College Tri-Cities OneStop Career Center
a. I have never utilized a Career Center service or resource
b. I have utilized a workshop
c. I have utilized career advising
d. I have utilized a job fair or recruitment event/service
e. I have utilized the Career Center website or Career Center social media
f. I don't know

23. Are you currently employed?
a. Yes
b. No

24. Are you a first-generation college student (first person in your immediate family to attend college)
a. Yes
b. No
c. Decline to state

25. Do you currently receive financial aid or scholarships?
a. Yes
b. No
c. I don't know

26. Please select the ethnicity in which you identify (select all that apply)
a. American Indian
b. African American
c. Asian/Pacific Islander
d. Hispanic
e. White
f. Multi/Biracial
g. Other
h. Decline to state

27. How do you identify your gender?
a. Woman
b. Man
c. Genderqueer/Gender Non-Conforming
d. Trans Woman
e. Trans Man
f. Another Identity
g. I don't know 
h. Decline to state

28. How do you identify your sexual orientation?
a. Asexual
b. Bisexual
c. Gay
d. Heterosexual (straight)
e. Lesbian
f. Pansexual
g. Queer
h. I don't know/Questioning
i. Another orientation
j. Decline to State

29. Are you a Veteran?
a. Yes
b. No
c. I don't know
d. Decline to state

30. Are you an individual with a disability (physical, mental health, learning, etc.)
a. Yes
b. No
c. I don't know
d. Decline to state

Please let us know how we're doing by providing us with feedback, recommendations, ideas, and comments. Let us know what you expect from your Career Center. 
60| P a g e 


\section{SOURCES CONSULTED}

Alameda County Workforce Development Board [ALWDB] (nd). About. Retrieved from http://www.acwdb.org/about

Anderson, K. H., \& Burkhauser, R. V. (1991). Mixed signals in the job training partnership act. Growth \& Change, 22(3), 32.

Bassi, L. J. (1983). CETA -- Did it Work?. Policy Studies Journal, 12(1), 106-118. doi:10.1111/1541-0072.ep11780368

Braun, J. \& Rossi, A. (Producers), Rossi, A. (Director). (January 18, 2014). Ivory Tower [Motion picture]. United States: CNN Films

Browning, B. \& Cox, L. (2017). Community Based Organization Master Contract. [Contract Document] Alameda County: Alameda County Workforce Development Board [ACWDB] \& Ohlone College.

CA.GOV (nd). America's Job Center of California: Job Center Locator. Retrieved from http://www.americasjobcenter.ca.gov/Job_Center_Locator.aspx

Career Services. (2010). Higher Education Abstracts, 45(4), 236-237. doi:10.1111/j.21501092.2010.00013_7.x

Cohen, A., Timmons, J. C., \& Fesko, S. L. (2005). The Workforce Investment Act. Journal Of Disability Policy Studies, 15(4), 221-230

Decker, P. T., \& Berk, J. A. (2011). Ten years of the Workforce Investment Act (WIA): Interpreting the research on WIA and related programs. Journal Of Policy Analysis \& Management, 30(4), 906-926. doi:10.1002/pam.20597

Despeaux, J. M., Knotts, H. G., \& Schiff, J. S. (2014). The Power of Partnerships: Exploring the Relationship between Campus Career Centers and Political Science Departments. Journal Of Political Science Education, 10(1), 37-47 doi:10.1080/15512169.2013.860877

Dey, F., \& Cruzvergara, C. (2014). Evolution of Career Services in Higher Education. New Directions for Student Services, 2014(148), 5-18

Ginn, J. (2015). Workforce Innovation and Opportunity Act 101. Capitol Ideas, 58(2), 22

Guttman, R. (1983). Job Training Partnership Act: new help for the unemployed. Monthly Labor Review, 106(3), 3. 
Haskins, R., \& Margolis, G. (2015). The Workforce Innovation Fund Initiative. In Show Me the Evidence: Obama's Fight for Rigor and Results in Social Policy (pp. 168-187). Brookings Institution Press. Retrieved from http://www.jstor.org/stable/10.7864/j.ctt7zsvr9.10

Holland, B. (2016). Both sides now: Toward the dual customer approach under the Workforce Innovation and Opportunity Act in the United States. Local Economy: The Journal of the Local Economy Policy Unit, 31(3), 424-441

Holzer, H. (2012). Better Skills for Better Jobs. Issues in Science and Technology, 28(2), 31-40. Retrieved from http://www.jstor.org/stable/43315592

Holzer, H. (2013). Creating Effective Education and Workforce Policies for Metropolitan Labor Markets in the United States. In Perna L. (Ed.), Preparing Today's Students for Tomorrow's Jobs in Metropolitan America (pp. 245-259). University of Pennsylvania Press. Retrieved from http://www.jstor.org/stable/j.ctt3fhqnp.14

Katc.com, (2017). First-of-its-kind workforce collaboration in Louisiana. Retrieved from http://www.katc.com/story/36640991/first-of-its-kind-workforce-collaboration-inlouisiana

Kleinbach-Sauter, H., Ganapathy, B., \& Fraser, E. (2015, January). STEM 2.0 An Imperative for Our Future Workforce. Diplomatic Courier. pp. 58-61

LaRose, C. (2015). College Career Services and WIOA [SlideShare]. Retrieved from https://www.slideshare.net/colleenlarose 7/college-career-services-and-wioa

Marquette, J. (2016). Workforce Innovation and Opportunity for Youth with ASD and Developmental Disabilities. Exceptional Parent, 46(10), 25-27

Mason, S. (2008). Policy Design and Regional Cooperation under the Workforce Investment Act. State \& Local Government Review,40(2), 101-114. Retrieved from http://www.jstor.org/stable/25469782

Ohlone College (April, 2018). Tri-Cities One-Stop Career Center: WIOA Orientation Video. Retrieved from http://tricitiesonestop.com/wiaorientation2.php

Ohlone College (2017). Tri-Cities One-Stop Career Center: Who We Are. Retrieved from http://www.tricitiesonestop.com/about2.php

Ray-Leonetti, J. (2017). Workforce Innovation and Opportunity Act. NonProfit Pro, 15(1), 1010,8. Retrieved from http://search.proquest.com.libaccess.sjlibrary.org/docview/1928308440?accountid=10361 
Ross, M. \& Holmes, N. (2017). Meet the out-of-work: Local profiles of jobless adults and strategies to connect them to employment. Metropolitan Policy Program at Brookings. Retrieved from https://www.brookings.edu/research/meet-the-out-of-work

Schaub, M. (2012). The Profession of College Career Services Delivery: What College Counselors Should Know About Career Centers. Journal Of College Student Psychotherapy, 26(3), 201-215. doi:10.1080/87568225.2012.685854

Shaw, K., \& Rab, S. (2003). Market Rhetoric versus Reality in Policy and Practice: The Workforce Investment Act and Access to Community College Education and Training. The Annals of the American Academy of Political and Social Science, 586, 172193. Retrieved from http://www.jstor.org/stable/1049725

Studley, J. (2016). Career Readiness Meets Institution-wide Outcomes Measures. National Association of Colleges and Employers (NACE). Retrieved from http://www.naceweb.org/career-readiness/trends-and-predictions/career-readiness-meetsinstitution-wide-outcomes-measures

United States Department of Labor (nd). WIOA Overview. Retrieved from https://www.doleta.gov/WIOA/Overview.cfm 